INTERNATIONAL

FOOD POLICY

RESEARCH

INSTITUTE

IFPRI

IFPRI Discussion Paper 01364

August 2014

\title{
Environmental Migration and Labor Markets in Nepal
}

\author{
Jean-François Maystadt
}

Valerie Mueller

Ashwini Sebastian

Development Strategy and Governance Division 


\section{INTERNATIONAL FOOD POLICY RESEARCH INSTITUTE}

The International Food Policy Research Institute (IFPRI), established in 1975, provides evidence-based policy solutions to sustainably end hunger and malnutrition and reduce poverty. The Institute conducts research, communicates results, optimizes partnerships, and builds capacity to ensure sustainable food production, promote healthy food systems, improve markets and trade, transform agriculture, build resilience, and strengthen institutions and governance. Gender is considered in all of the Institute's work. IFPRI collaborates with partners around the world, including development implementers, public institutions, the private sector, and farmers' organizations, to ensure that local, national, regional, and global food policies are based on evidence.

\section{AUTHORS}

Jean-François Maystadt (JeanFrancois.Maystadt@kuleuven.be) was an associate research fellow in the Development Strategy and Governance Division of the International Food Policy Research Institute, Washington, DC, when he wrote this work. He is currently a senior lecturer in the Department of Economics at Lancaster University Management School, Lancaster, UK.

Valerie Mueller (v.mueller@cgiar.org) is a research fellow in the Development Strategy and Governance Division of the International Food Policy Research Institute, Washington, DC.

Ashwini Sebastian (asebast1@umd.edu) is a student research affiliate in the Department of Agricultural and Resource Economics at the University of Maryland, College Park, MD, US.

\section{Notices}

1. IFPRI Discussion Papers contain preliminary material and research results and are circulated in order to stimulate discussion and critical comment. They have not been subject to a formal external review via IFPRI's Publications Review Committee. Any opinions stated herein are those of the author(s) and are not necessarily representative of or endorsed by the International Food Policy Research Institute.

2. The boundaries and names shown and the designations used on the map(s) herein do not imply official endorsement or acceptance by the International Food Policy Research Institute (IFPRI) or its partners and contributors.

Copyright 2014 International Food Policy Research Institute. All rights reserved. Sections of this material may be reproduced for personal and not-for-profit use without the express written permission of but with acknowledgment to IFPRI. To reproduce the material contained herein for profit or commercial use requires express written permission. To obtain permission, contact the Communications Division at ifpri-copyright@cgiar.org 


\section{Contents}

Abstract $\quad$ V

Acknowledgments $\quad$ vi

1. Introduction 1

2. Vulnerability and Labor Maket Conditions in Nepal 3

3. Data 6

4. Methodology $\quad 8$

5. Results 10

6. Conclusions 20

Appendix: Supplementary Tables and Figures $\quad 21$

$\begin{array}{ll}\text { References } & 28\end{array}$ 


\section{Tables}

2.1 Summary statistics, individual characteristics of migrants and natives aged 18-65, weighted, 2003 and 2010

5

5.1 Determinants of in- and out-migration rates

5.4 Effect of net migration rate on wages for nonmigrant household heads aged 18-65 (second stage)

5.5 Effect of net migration rate on wages for nonmigrant household heads aged $18-65$, by skill (second stage)

5.6 Effect of net migration rate on employment for nonmigrant household heads aged 18-65 (second stage)

5.7 Effect of net migration rate on unemployment for nonmigrant household heads aged 18-65

5.8 Effect of net migration rate on nonmigrant household expenditure patterns

5.9 Nonmigrant household financial and capacity constraints of enterprises ( own enterprise), weighted, 2003 and 2010

A.1 Effect of net migration rate on wages using alternate instruments derived from adjusted OLS method for nonmigrant household heads aged 18-65 (second stage)

A.2 Effect of net migration rate on wages using alternate instruments derived from adjusted OLS method for nonmigrant household heads aged $18-65$, by skill (second stage)

A.3 Testing exclusion restrictions, including spatially lagged weather shock and climate variables in own district (only net-migration rate coefficients and main outcomes reported)

A.4a Relationship between skill and wages for nonmigrant household heads, aged 18-65

A.4b Testing exclusion restrictions, including spatially lagged weather shock and climate variables in own district (employment outcomes only)

A.4c Testing exclusion restrictions, including spatially lagged weather shock and climate variables in own district (wage outcomes only)

A.5 Reduced form regressions of predicted migration on wages

A.6 Reduced form regressions of predicted migration on employment

\section{Figures}

5.1 Actual and predicted net migration, Nepal 2003 and 2010

5.2 Estimated effects of predicted net migration on formal-sector wages, Nepal 2003 and $2010 \quad 14$

A.1 Droughts in Nepal, cumulative over four years, 2003 versus $2010 \quad 21$

A. 2 Conflicts in Nepal, cumulative over previous four years, 2003 versus 2010 


\begin{abstract}
While an emerging literature cites weather shocks as major determinants of migration, scant evidence exists on how such migration impacts the labor markets of receiving communities in developing countries. We address this knowledge gap by investigating the impact of weather-driven internal migration on labor markets in a post-conflict country, Nepal, using household survey data in 2003 and 2010. In this period, 3 percent of individuals moved out of their district of origin during the four years preceding each survey round. Contrary to the conventional narrative, we find prevailing environmental and conflict factors entice workers with positively selected attributes (such as education and skill) to migrate. Marked skill

differences between migrants and the native population render wage effects in the formal sector: an increase of 1 percentage point in migration reduces wages in the formal sector by 4.8 percentage points. The absence of wage effects in the informal sector is consistent with the exit of low-skilled native workers from the labor market. To inform pathways to labor market resilience, future research is needed to understand the constraints migrants face in starting their own enterprises and the drivers of labor market exits among the low-skilled natives.
\end{abstract}

Keywords: migration, Nepal, labor markets

JEL codes: $132,018, Q 54$ 


\section{ACKNOWLEDGMENTS}

The authors thank Viviane Hoffman and all participants of conferences and seminars where previous versions of this paper were presented for their comments and suggestions. J-F. Maystadt is grateful to the Center for Institutions and Economic Performance (LICOS), KU Leuven and the International Food Policy Research Institute (IFPRI) for their support during his associate research fellow position, during which this research was initiated. The authors also acknowledge financial support from the the CGIAR Research Program on Policies, Institutions, and Markets (PIM). 


\section{INTRODUCTION}

Migration is understood to be a key mode of adaptation to extreme climatic events (IPCC 2014). Rural workers search for employment elsewhere to mitigate income losses temporarily or move permanently if the damages are severe (Halliday 2006; Feng, Krueger, and Oppenheimer 2010; Dillon, Mueller, and Salau 2011; Gray and Mueller 2012a,2012b ; Marchiori, Maystadt, and Schumacher 2012; Gray and Bilsborrow 2013; Bohra-Mishra, Oppenheimer, and Hsiang 2014; Mueller, Gray, and Kosec 2014). An emerging challenge in the climate change debate is to reconcile whether such adaptation bears additional consequences for human security and livelihoods (IPCC 2014).

Measures of the consequences of migratory flows on the labor markets of hosting communities in industrialized countries are ubiquitous (Card 1990, 2005; Borjas 2005, 2006; Boustan, Fishback, and Kantor 2010; Ottaviano and Peri 2012; Pugatch and Yang 2011). In developing countries, the issue has been investigated from the perspectives of either the migrants (Beegle, De Weerdt, and Dercon 2011; Grogger and Hanson 2011; de Brauw, Mueller, and Woldehanna 2013), their countries of origin (Adams and Page 2005; Hanson 2009, for a review), or the households directly linked to migrants (Woodruff and Zenteno 2007; Yang 2008). Scant evidence exists on how internal migration impacts the labor markets of receiving communities in developing countries, let alone the implications of disaster-driven migration (Kleemans and Magruder 2012; El Badaoui, Strobl, and Walsh 2014; Strobl and Valfort 2013). We address this knowledge gap by investigating the impact of weather-driven migration on internal labor markets in a conflict-prone country, Nepal.

Standard models predict immigration is detrimental to workers that show high degree of substitutability with migrants (Johnson 1980a, 1980b; Altonji and Card 1991; Borjas 2003, 2006; Card and Lemieux 2001; Borjas and Katz 2007; Ottaviano and Peri 2012). Migrants are implicitly assumed to be low skilled and to substitute natives with comparable skills. Recent work in Uganda supports these assertions (Strobl and Valfort 2013). Elsewhere, migrants are characterized as highly skilled, yet displace low-skilled workers (Kleemans and Magruder 2012). Kleemans and Magruder (2012) speculated that binding constraints (such as minimum wage laws) in the formal sector can create a wedge between formaland informal-sector wages. These conditions further render substitution effects more pronounced among disadvantaged natives. Thus, immigration displaces low-skilled workers, causing a decline in the wages of (less educated) native workers predominantly employed in the informal sector (Kleemans and Magruder 2012).

Exposure to civil war ${ }^{1}$ and environmental degradation, and the linkages of these factors to rural-urban migration ${ }^{2}$ render Nepal an interesting context in which to study the spillover effects of adaptation, with a direct focus on nearby labor markets. We apply the methodology of Boustan, Fishback, and Kantor (2010) to address biases inherent in the immigration literature: the self-selection of migrants at origin, the selection of migrant destinations, and native displacements. The methodology allows for the full exploitation of bilateral migration flows in order to identify plausibly exogenous push factors at origin and pull factors at destination. In contrast, using approximations of push factors as alternative instruments for internal migration, such as spatially lagged weather shocks, raises concerns regarding the validity of the exclusion restriction due to spatial spillovers resulting from these shocks. ${ }^{3}$

We provide a few modifications to the Boustan, Fishback, and Kantor (2010) methodology to improve identification in the first stage and adapt the methodology to the contextual setting of our study.

\footnotetext{
${ }^{1}$ Urbanization and labor markets have been affected by conflicts in other settings (Kondylis 2010; Maystadt and Verwimp 2014; Alix-Garcia and Bartlett 2012; Alix-Garcia, Bartlett, and Saah 2013).

${ }^{2}$ Environmental degradation and weather shocks have been argued to increase rural-urban migration in Nepal (Shrestha and Bhandari 2005; Massey, Axinn, and Ghimire 2010).

3 The problem of spatial spillovers is less of an issue when using approximations of shocks at origin to study international migration (Munshi 2003; Pugatch and Yang 2011), since shocks occur outside the labor markets under investigation and the existence of spatial spillovers can be directly tested. In our study of internal migration in Nepal, we will nonetheless follow Pugatch and Yang (2011) to directly test the existence of spatial spillovers.
} 
First, we model net migration rates between districts in Nepal, accounting for lagged weather anomalies, in addition to conflict and historical migration flows, and their interactions with river density. Thus, we expand on the push-pull factors previously considered while introducing a dynamic estimation framework. Controlling for historical migration flows is crucial to decipher the relative importance of natural disasters and conflict events on immigration consequences. Second, we differentiate consequences on the labor market by native worker skills to interpret the empirical findings from theoretical predictions in the literature (Altonji and Card 1991; Kleemans and Magruder 2012).

Our dynamic model of out-migration rates indicates weather extremes are a prominent driver of out-migration in Nepal, corroborating earlier work. An increase by 1 standard deviation in the exposure to floods (droughts) reduces out-migration rates by approximately 18 percent ( 20 percent) in areas with mean river density. The effect of flooding is reversed for individuals in areas densely populated with rivers. Increasing the number of conflict events by 1 standard deviation also encourages out-migration to a lower degree, by 6 percent.

Incorporating historical migration rates in our dynamic model provides two interesting perspectives. First, including auxiliary controls is crucial in this literature, as their omission can bias parameter estimates. Second, it suggests that weather extremes are of equal importance to these omitted factors. An increase of 1 standard deviation in the lagged out-migration rate increases future out-migration rates by about 22 percent. The corresponding increase for in-migration rates is even larger (at about 62 percent), reflecting strong network effects.

We find such prevailing factors push a more distinct group of individuals to migrate (Kleemans and Magruder 2012; Strobl and Valfort 2013). Approximately half of the migrant population had completed 10 years of schooling, relative to 18 percent of natives, in 2010. These high-skilled migrants potentially saturate the formal sector, where one-fourth of natives are employed. These marked imbalances between the characteristics of the migrants and of the native population accentuate wage effects in the formal sector: an increase of 1 percentage point in net migration reduces wages in the formal sector by 4.8 percentage points.

Wage effects are concentrated in the formal sector, despite observed reductions in the employment of natives in the informal sector. The absence of wage effects in the informal sector is consistent with the exit of native workers from the informal labor market. We additionally show immigration largely leads to the unemployment of low-skilled natives. An increase of 1 percentage point in net migration leads to an increase of 1.5 percentage points in the unemployment of unskilled workers.

Our findings have implications for both the immigration and environmental migration literatures. First, migration is found to strongly affect labor outcomes in hosting districts in Nepal. While migrants bring skills to host economies, their presence depresses the wages of workers in the formal sector (in contrast to the findings of Kleemans and Magruder [2012] in Indonesia) and causes workers to exit the labor market altogether. Second, our results suggest vulnerability to weather extremes is not limited to those at the source of exposure. Conflict and flooding in areas populated by rivers displace people. The vulnerability of populations in external communities has spillover effects on migrant hubs. If the highly skilled workers are most affected, reductions in their purchasing power likely incur losses to providers of their services and goods. Understanding the constraints migrants face in starting their own enterprises and the drivers of labor market exits among the low-skilled natives will inform pathways to labor market resilience. 


\section{VULNERABILITY AND LABOR MARKET CONDITIONS IN NEPAL}

Flooding is not uncommon in Nepal and can potentially lead to an increase in migration, away from rivers and toward low-lying land (Banister and Thapa 1981; Shrestha 1999; Massey, Axinn, and Ghimire 2010). Our analysis covers periods of unprecedented increases in the frequency and severity of floods and landslides (Figure 2.1). Small-scale floods occurred (prior to 2002) followed by widespread exposure (in 47 districts), displacing hundreds of thousands by 2002 (UN report 2002). The 2007 floods displaced more than 19,000 households (Dartmouth Flood Observatory and CRED 2014). A flood of an even larger magnitude occurred in eastern Nepal in 2008 as a result of a breach in an embankment at the Indo-Nepali border, displacing 42,000 households across several villages (UNOCHA 2008). Flooding and landslides affected the far western and midwest regions during the heavy monsoon period of 2009: 4,000 households were displaced and the food stock of 25,000 families lost (UNOCHA 2009).

Figure 2.1 Floods in Nepal, cumulative over previous four years, 2003 versus 2010
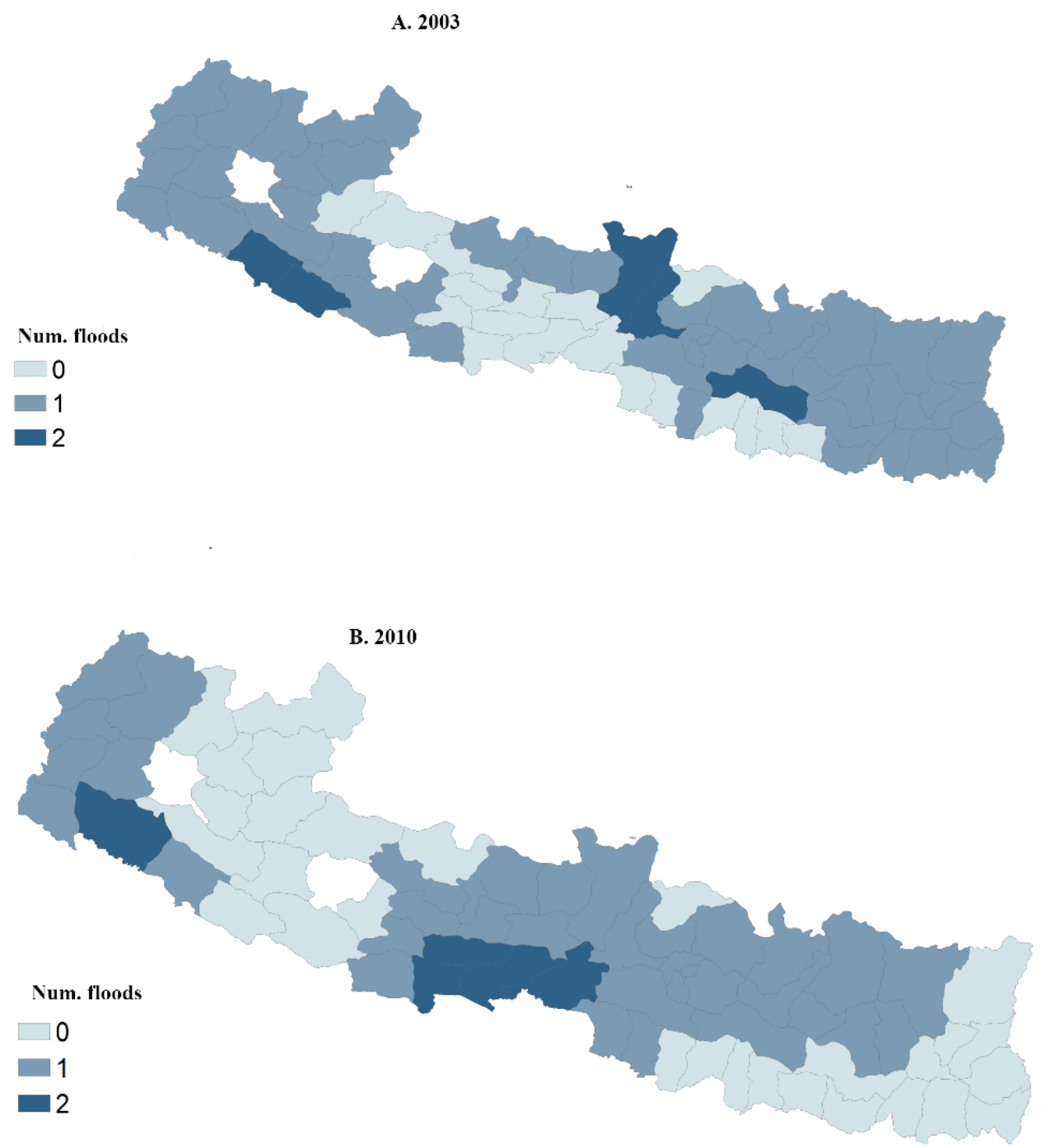

Source: Authors' own representation.

Note: Districts not used are omitted from maps. 
Drought risk is rare and tends to occur during the winter, the regular monsoon period. Western and eastern Nepal have experienced episodes of consecutive droughts since $2000^{4}$. These culminated in a severe drought over the period November 2008 to February 2009, with precipitation 50 percent below the seasonal average (Wang, Yoon, and Gillies 2013).

Civil conflict was also a major factor driving migration in Nepal from 1999 to 2006 (Bohra-Mishra 2011). A Maoist insurgency began in the Rolpa district in western Nepal and much of the conflict was concentrated in mountainous and hilly terrain, and in poorer areas. The decade-long conflict led to the loss of more than 13,000 lives (Do and Iyer 2010). There was considerable variation in the intensity of conflict across the country; ${ }^{5}$ the Maoists controlled several districts in eastern and western Nepal by 2005 (Murshed and Gates 2005). Violent outbreaks led to the movement of political refugees away from conflict-prone areas. The predicted probability of migration decreased for moderate levels of violence and increased as violence became more intense (Bohra-Mishra 2011).

Local migration in Nepal driven by environmental and political factors is concentrated among more skilled and educated workers. Massey, Axinn, and Ghimire (2010) found that environmental decay, as indicated by falling agricultural productivity, serves to increase the odds of local migration. Specifically, the odds of moving are significantly higher for individuals with more years of schooling and holding salaried occupations, which is likely to indicate greater skill and therefore greater potential returns on human capital from migration. Among locally migrating adult males in Nepal compared with non migrants, the former are younger and more educated (Fafchamps and Shilpi 2013). Similar to environmentally driven migration, within conflict areas, migrants who move both within and across districts tend to be younger and more educated, and to hold salaried jobs (Bohra-Mishra 2011). These disparities across movers and nonmovers increase when migration is across districts.

The above migration trends suggest displacement associated with environmental disasters explains only a small portion of the mobility patterns in Nepal. Acknowledging additional push-pull factors, such as conflict and economic drivers, is crucial to provide an unbiased understanding of migration and its consequences on neighboring districts. This fact influences our decision to modify the Boustan, Fishback, and Kantor (2010) identification strategy to incorporate conflict and a dynamic component to proxy additional drivers of migration.

Previous work on environmental and conflict displacement suggests the relatively skilled will tend to move out of district, between-district migration being the scope of our study. Classifying workers by sector, we observe both migrants and nonmigrants tend to be employed in the informal sector. However, migrants are increasingly employed in the formal sector (Table 2.1). A greater proportion engage in service-sector work; 39 percent of migrants compared to 17 percent of nonmigrants in 2010 (Table 2.1). Nonmigrants are also disproportionately employed in agriculture. While the agricultural sector remains an important contributor to Nepal's economy, from 1965 to 2010, the share of gross domestic product accounted for by agriculture fell from 70 percent to 30 percent, while the share accounted for by services increased from 20 percent to more than 50 percent (ILO 2010). These trends suggest that immigration is likely to affect services, the sector that employs the greatest share of migrants. Moreover, labor market adjustments following a shift in labor supply may be constrained given the declining role of agriculture in the economy.

\footnotetext{
${ }^{4}$ See Figure A.1 in the appendix.

${ }^{5}$ See Figure A.2 in the appendix.
} 
Table 2.1 Summary statistics, individual characteristics of migrants and natives aged 18-65, weighted, 2003 and 2010

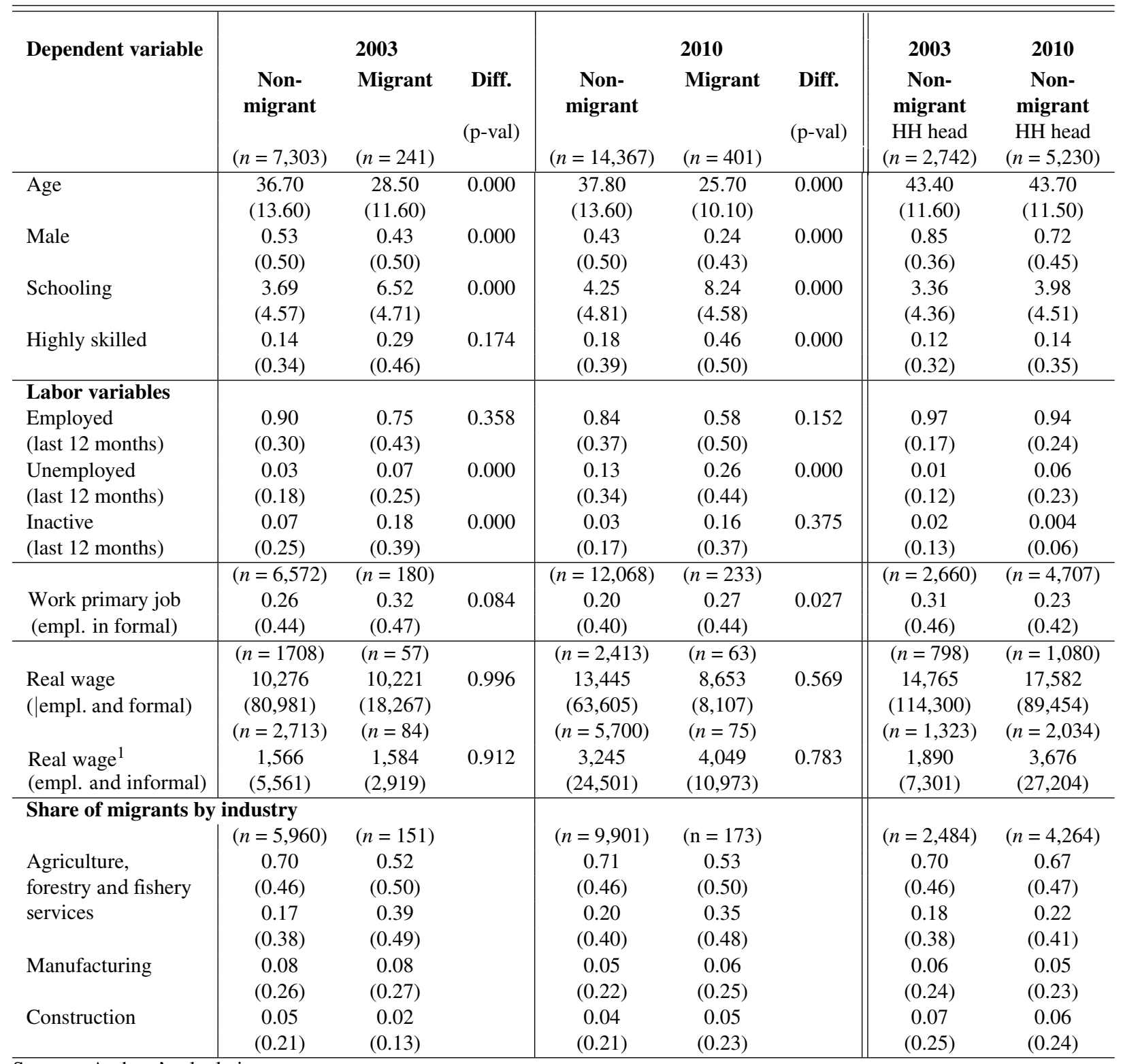

Source: Authors' calculations.

Note: $\quad H H=$ Household. Real wages expressed at the monthly level in 2010 rupees. 1 Real monthly wage for individual in informal sector constructed using agricultural or enterprise revenues per worker. 2 Real monthly wage for household in the informal sector is household agricultural or enterprise revenue. 


\section{DATA}

Our analysis draws from several data sources. First, migration and employment data are taken from two waves of the nationally representative Nepal Living Standards Survey (NLSS): 2003 and 2010. Second, we use the Armed Conflict Location and Event Dataset (ACLED), which documents georeferenced conflict events through 2010, to measure conflict exposure. Third, to create weather anomaly variables, we use $1 \times 1$ degree gridded satellite-based weather data provided by the POWER (Predicted of Worldwide Energy Resource) project of the National Aeronautics and Space Administration (NASA) of the United States for the years 1981 to 2013 (NASA 2014). Fourth, gridded population data are extrapolated from the Center for International Earth Science Information Network at Columbia University. Fifth, river networks and geographic characteristics (such as distance) are extracted from the United States Geological Survey HydroSHEDS (Hydrological Data and Maps Based on Shuttle Elevation Derivatives at Multiple Scales dataset). ${ }^{6}$ Below we elaborate on how our outcomes and explanatory variables are constructed from the aforementioned datasets.

\section{Definition of Variables}

\section{Migration}

We create migration flows using the migration information of 7,000 and 14,000 individuals (residing in 3,954 and 5,556 households in 69 districts $^{7}$ ) in 2003 and 2010, respectively. Inflows are based on individuals who reported moving to district $k$ from district $j$ in year $t$ using NLSS sampling weights for population-based inferences. Bilateral migration outflows are similarly defined. We restrict our focus to inflows and outflows for four years preceding the 2003 and 2010 surveys to minimize the impact of recall bias and ensure sufficient coverage of conflict and weather events in the period observed. ${ }^{8}$ Population figures derived from the 1995 NLSS are then used to further convert the migration flows into shares of migrants moving into and out of each district $k$ from each district $j$ for each year. This procedure creates two $69 \times 69$ matrices of bilateral in- and out-migration rates at the district level, which are used to predict net migration rates, the key variable for the identification of the impact of migration in the labor regressions.

\section{Conflict}

A conflict event is defined as a single altercation in which one or more groups use force for a political end (Raleigh et al. 2010). Following this definition, the number of conflict events per square kilometer is defined by district-year for the four years prior to 2003 and 2010. Between 1996 and 2006, the end of the civil war, about 3,030 conflict events were reported in the ACLED dataset for Nepal.

\section{Weather Anomalies}

We create seasonal flood and drought indicator variables, for the same period covering migration flows, for each $1 \times 1$ degree grid that overlaps a district in a given year. Heavy monsoon is from June to September. Regular monsoon is from November in the previous year through February of the current year. A flood shock indicator, for each grid in a given year, is set to 1 if cumulative rainfall over the heavy monsoon season exceeds the 90th percentile of the time-series distribution. Similarly, a drought shock indicator, for each grid in a given year, is set to 1 if cumulative rainfall over the regular monsoon season falls below the 10 th percentile of the distribution.

\footnotetext{
${ }^{6}$ The data source is http://hydrosheds.cr.usgs.gov/index.

7 In total, six districts are excluded from our panel because they were omitted from the 2003 and 2010 surveys. In 2003, Accham, Mustang, and Rasuwa districts were unreachable due to conflict. Dolpa, Ilam, and Manang districts were omitted in 2010.

${ }^{8}$ Modifying the number of years over which migration is observed has little impact on the estimation of predicted migration rates.
} 
Annual district-level flood and drought indicators are set to 1 if a flood or drought occurs in any grid overlapping the district. The flood and drought variables are interacted with river density data to capture an additional dimension of district exposure to the weather anomalies. River density is calculated as the length of the river segments in kilometers divided by each district area.

\section{Labor Market Outcomes}

Our labor supply variables focus on the employment status of the individual. An individual is considered employed if he reported working in the last 12 months prior to the survey interview. Otherwise, the individual is categorized as unemployed (did not work nor engage in domestic activities in the last 12 months) or inactive (did engage in domestic activities in the last 12 months).

Two stratifications are made in the analysis to facilitate the interpretation of results. The first stratification is based on the sector of employment, which relies on the NLSS definition. We also stratify the sample by skill, whereby individuals having more than 10 years of schooling are characterized as highly skilled and others are considered low skilled.

Individual and household earnings over a 12-month period are used to construct monthly formaland informal-sector wages, respectively. We use the national consumer price index to deflate 2003 wages into 2010 real terms. Monthly wages for formal-sector workers are taken directly from the survey. For the majority of workers employed in the informal sector, we base earnings on revenues from own farms and enterprises. To construct individual monthly earnings, we divide monthly revenues by the number of members in the household reported to be employed in the enterprise.

Our measure of informal earnings may under- or overestimate true individual earnings in the informal sector. We might systematically overestimate revenues per capita by omitting hired employees from the denominator (because they were missing from the agricultural module). On the other hand, we may underestimate individual earnings because we are unable to clarify which household members were employed by the enterprise on a permanent basis.

Because household enterprises are more the rule than the exception, we restrict the analysis of migration impacts to the sample of household heads. Particularly for the informal sector, adding members from larger households may attenuate the effect of immigration inasmuch as their employment status may depend on their relative position in the household and other joint household decisions. Since restricting the focus to household heads sufficiently reduces the initial sample size, we detail how heads differ from the rest of the natives in the Summary Statistics section.

\section{Summary Statistics}

Table 2.1 compares the characteristics of migrants, nonmigrants, and nonmigrant household heads in our sample. Migrants tend to be younger and more educated than nonmigrants, and a greater percentage are women. The proportion of migrants that completed 10 or more years of schooling is 29 percent, compared with 14 percent of non-migrants in 2003. These differences widen by 2010, when 46 percent of migrants are considered skilled according to our definition, compared with 18 percent of nonmigrants. Given the skill differentials, it is not surprising that a greater percentage of migrants work in the formal sector.

Restricting the nonmigrant sample to household heads changes the distribution of gender and age characteristics with negligible effects on educational endowment. Focusing on the heads produces a sample closer to full employment. As expected, household heads obtain greater formal- and informal-sector wages on average (than the complete sample of nonmigrants), and the difference is persistent over time. 


\section{METHODOLOGY}

We employ the Boustan, Fishback, and Kantor (2010) methodology to account for changes in native labor market outcomes attributable to immigration, using the following empirical model:

$$
Y_{i j t}=\alpha_{1}+\beta M_{j t}+\lambda X_{i j t}+\gamma Q_{j t}+\delta_{j}+\delta_{t}+\varepsilon_{i j t}, t=[2003,2010]
$$

The dependent variable $Y$ represents the non-migrant labor outcomes (employed, unemployed, and $\log$ monthly wages) for individual level $i$, living in area $j$ at time $t$. Labor supply and wage variables are a function of several factors: the net labor migration rates $M$ to area $j$ over the last four years, a vector of demographic controls $X$ that reflect one's earning potential (age, gender, education), a vector of location characteristics $Q$ (urban destination), a location fixed effect $\delta_{j}$ to reflect labor market differences at the regional level, and a time fixed effect $\delta_{t}$ to account for time trends. Errors are clustered at the district level to allow for correlation between individuals within district-level labor markets.

To deal with the endogeneity of the net migration rate $M$, predicted in- and out-migration rates are used as instruments for the observed net migration rates (Boustan, Fishback, and Kantor 2010). ${ }^{9}$ Equations (2) through (4) delineate how the predicted in-migration rate is computed. Out-migration rates are calculated in a similar fashion to compute net migration rates. To compute the in-migration rate for location $j$, we must first predict the in-migration flows, $I M_{j t}$, of migrants to location $j$. This is the product of the number of migrants leaving location $k$ and the probability that these migrants move from location $k$ to location $j, \widehat{P_{k j t}}$, where $\widehat{O_{k t}}$ denotes the out-migration rate. The instrument for the in-migration rate is the predicted flow in equation (2) divided by district $j^{\prime}$ s population in 1995.

$$
\begin{aligned}
I M_{j t} & =\sum_{k \neq j}\left(\widehat{O_{k t}} \times \text { pop }_{k 1995}\right) \times \widehat{P_{k j t}}, \text { with } t=[2003,2010] \\
O_{k t} & =\alpha_{2}+\theta_{1} Z_{k t-1}+\theta_{2} M_{k t-1}+\delta_{k}+\delta_{t}+\varepsilon_{k t},
\end{aligned}
$$

with $\quad t=[2000,2001,2002,2003,2007,2008,2009,2010]$

$$
P_{k j t}=\alpha_{3}+\phi f\left(d_{k j}\right)+\delta_{t}+\varepsilon_{k t}, \text { with } t=[2003,2010]
$$

In equation (3), we modify the out-migration rate, $O_{k t}$, equation from Boustan, Fishback, and Kantor (2010) and later Strobl and Valfort (2013) in three ways. First, the out-migration rate is influenced by origin weather shocks (floods, droughts and their interaction with river density), as well as by past conflict events $\left(Z_{k t-1}\right)$. Although the consistency of our results does not depend on the addition of these interaction terms and the conflict variables, such modifications are motivated by the vulnerability of Nepali households to floods, as described in Section 2. Second, we estimate out-migration flows using a linear probability model with district and time fixed effects. Third, we improve the predictive power of out-migration rates by estimating a dynamic model, incorporating lagged migration rates. A standard system generalized method of moments (GMM) dynamic model (Blundell and Bond 1998) is applied with robust standard errors. ${ }^{10}$ The predictive power of the dynamic model is assessed against an alternative model, ordinary least squares (OLS) with standard errors robust to time and spatial correlation (Conley 1999). We assume that spatial dependency disappears beyond a cutoff point of 64 kilometers, which

\footnotetext{
${ }^{9}$ We follow Boustan, Fishback, and Kantor (2010) in how we compute the standard errors in the first- and second-stage regressions. The first-stage regressions use block-bootstrapped standard errors (clustering at the district level) to account for the fact that the predicted in- and out-migration rates are generated regressors.

${ }^{10}$ The method provides more efficient estimates than difference GMM estimations (Arellano and Bond 1991) but requires an additional assumption with respect to stationarity. We apply Fisher' test for panel unit root using an augmented Dickey-Fuller test (Maddala and Wu 1999). For our main variables reported in Table 5.2, we can reject the null hypothesis of nonstationarity in all variables at any reasonable confidence level. One exception is the number of conflicts per square kilometer, noting that our results do not depend on the inclusion of the conflict variables (Table 5.1).
} 
corresponds to the maximum distance between the centroids of any pair of neighboring districts. We also allow for time dependency of up to two years, which is larger than the minimum time lag ( $T$ powered 0.25 ) recommended by Green (2003) and Hsiang (2010).

For each source location $k$, the probability of moving from location $k$ to location $j$ is then estimated by a dyadic model in equation (4), which depends on the proximity between locations $k$ and $j$, $d_{j k}$. We define the proximity as a Euclidian distance between locations and allow for a nonmonotonic relationship with the introduction of a quadratic term. We estimate (4) using a linear probability model with time fixed effects $\delta_{t}$ to account for unobserved time-specific variables that influence migration. Standard errors are clustered at the origin level.

Our identification strategy hinges on the assumption that the predicted out-migration rates from sending districts affect individual labor market outcomes at the destination only through their effect on net migration. ${ }^{11}$ By focusing on district-level migration rates, we essentially reduce the potential for the exclusion restriction to be violated due to the spatial correlation of shocks across cities and villages within the same district. Furthermore, by including district fixed effects, we control for unobserved factors at the destination that might be correlated with net migration and affect labor market outcomes.

The only credible threat to identification would come from spatial correlation between the variables used to predict out-migration from sending districts and unobserved local labor market conditions at the district level (Boustan, Fishback, and Kantor 2010; Pugatch and Yang 2011). This is certainly one rationale for lagging these variables when predicting out-migration. Yet we cannot rule out that (lagged) political and environmental shocks are correlated across districts and feature enough persistency to threaten the validity of the exclusion restriction. We will therefore test the robustness of our analysis in Section 5 by augmenting the regressions with spatially lagged political and environmental shocks that explicitly control for spatial correlation across districts.

\footnotetext{
11 The average net migration rate (Table 5.2) is slightly lower than rates observed in the US literature but within the realm for internal migration in developing countries (Strobl and Valfort 2013).
} 


\section{RESULTS}

\section{Results from the Regressions Used to Predict Net Migration Rates}

We first present the parameter and standard error estimates from the OLS version of (3) (column 3, Table 5.1). An increase of 1 standard deviation (that is, by 0.387 ) in flood incidence during the heavy monsoon (that is, 0.387 ) reduces the out-migration rate by 0.0009 (at mean river density). ${ }^{12}$ Given the mean value of the out-migration rate (0.005), the impact corresponds to a reduction of 18 percent. Flood exposure, particularly in areas with dense river networks, can push individuals out of their locations of origin. For example, consider individuals living in areas where the river density is 2 standard deviations above the mean. An increase of 1 standard deviation in flood incidence elevates their chance of out-migration by 3 percent.

Inferences on the flooding parameters are similar when based on the dynamic model (column 6, Table 5.1). At the cost of imposing an additional assumption with respect to the exogenous nature of past migration, ${ }^{13}$, the dynamic model is found to offer a better specification fit. The F-test of joint significance in the first-stage equation is slightly higher for the instruments resulting from the dynamic model. Our instrumental variables (predicted migration rates) and the interpretation of the remaining parameters are therefore based on our preferred specification, the dynamic model.

A major advantage of the dynamic model is the ability to control for auxiliary factors that affect historical migration rates. To give perspective on the relative importance of flooding on out-migration rates, auxiliary factors, as proxied through the lagged out-migration rate, influence out-migration rates by a similar order of magnitude. An increase of 1 standard deviation in historical out-migration rate augments out-migration rates by 22 percent compared with an 18 percent reduction from an equivalent increase in flooding exposure. While the number of conflicts also has a consistently positive effect on out-migration rates, the effects are smaller with an increase of 1 standard deviation, leading to a 6 percent increase in out-migration rates.

We briefly remark on the in-migration rate regression (column 12, Table 5.1). Lagged migration is the only statistically significant determinant. An increase of 1 standard deviation in historical in-migration rates is predicted to increase in-migration by 62 percent, reflecting strong network effects.

We next turn to the models used to predict the probabilities of moving from district $k$ to $j$ and vice versa (4). Both specifications suggest a convex relationship between the probability of moving and distance. For example, the probability is almost always negatively correlated with the linear term (for 124 and 127 of the 138 estimated pairs in $P_{k j}$ and $P_{j k}$, respectively) and positively correlated with the squared term (for 132 and 136 of the 138 estimated pairs in the same two specifications). The small sample of district pairs, however, influences the precision of our estimates. About 25 percent of the coefficients on the linear and squared distance variables are statistically significant at the 10 percent critical level in both probability specifications.

\footnotetext{
12 Descriptive statistics for district-level variables, which are used to compute the average partial effects, are given in Table 5.2.

13 To validate the consistency of the GMM estimator, the test for the first-order serial correlation rejects the null hypothesis of no correlation, while the hypothesis for second-order serial correlation cannot be rejected. The Sargan test for over identification does not reject the null hypothesis of zero correlation between the instrumental variables and the error term.
} 


\section{Table 5.1 Determinants of in- and out-migration rates}

\begin{tabular}{|c|c|c|c|c|c|c|c|c|c|c|c|c|}
\hline \multirow{3}{*}{ Dependent variable } & \multicolumn{6}{|c|}{ Out-migration rate } & \multicolumn{6}{|c|}{ In-migration rate } \\
\hline & \multicolumn{3}{|c|}{ OLS } & \multicolumn{3}{|c|}{ Dynamic model } & \multicolumn{3}{|c|}{ OLS } & \multicolumn{3}{|c|}{ Dynamic model } \\
\hline & (1) & (2) & (3) & (4) & (5) & (6) & (7) & (8) & (9) & (10) & (11) & (12) \\
\hline $\begin{array}{l}\text { Flood in heavy } \\
\text { monsoon at } t-1 \\
\text { Drought in regular } \\
\text { monsoon at } t-1 \\
\text { No. of conflicts } \\
\text { per sq km at } t-1 \\
\text { Out-migration } \\
\text { rate at } t-1 \\
\text { Flood in HM at } t-1 \times \\
\text { River density } \\
\text { Drought in RM at } t-1 \times \\
\text { River density }\end{array}$ & $\begin{array}{c}-0.002 * * * \\
(0.001) \\
-0.001 \\
(0.001)\end{array}$ & $\begin{array}{c}-0.002 * * * \\
(0.001) \\
-0.001 \\
(0.001) \\
-0.041 \\
(0.031)\end{array}$ & $\begin{array}{c}-0.014 * * * \\
(0.005) \\
-0.000 \\
(0.004) \\
-0.041 \\
(0.031)\end{array}$ & $\begin{array}{c}-0.002 * * * \\
{[0.001]} \\
-0.003 * * \\
{[0.001]} \\
\\
0.171 * * * \\
{[0.055]}\end{array}$ & $\begin{array}{c}-0.002 * * \\
{[0.001]} \\
-0.003 * * \\
{[0.001]} \\
0.028 \\
{[0.018]} \\
0.169 * * * \\
{[0.058]}\end{array}$ & $\begin{array}{c}-0.008^{* *} \\
{[0.004]} \\
0.005 \\
{[0.005]} \\
0.031 * \\
{[0.019]} \\
0.159 * * \\
{[0.062]} \\
0.033 * \\
{[0.019]} \\
-0.043 * * \\
{[0.022]}\end{array}$ & $\begin{array}{c}-0.000 \\
(0.000) \\
-0.001 \\
(0.000)\end{array}$ & $\begin{array}{c}-0.000 \\
(0.000) \\
-0.001^{*} \\
(0.000) \\
-0.100 * * * \\
(0.022)\end{array}$ & $\begin{array}{c}0.002 \\
(0.004) \\
-0.001 \\
(0.003) \\
-0.100 * * * \\
(0.022) \\
\\
\\
-0.017 \\
(0.023) \\
0.003 \\
(0.015)\end{array}$ & $\begin{array}{c}0.000 \\
{[0.000]} \\
0.001 \\
{[0.001]}\end{array}$ & $\begin{array}{c}0.000 \\
{[0.000]} \\
0.001 \\
{[0.001]} \\
0.035 \\
{[0.045]} \\
0.356^{*} * * \\
{[0.094]}\end{array}$ & $\begin{array}{c}0.000 \\
{[0.004]} \\
-0.001 \\
{[0.003]} \\
0.018 \\
{[0.019]} \\
0.370^{* * *} \\
{[0.100]} \\
-0.001 \\
{[0.021]} \\
0.009 \\
{[0.014]}\end{array}$ \\
\hline $\begin{array}{l}\text { Observations } \\
\text { R-squared } \\
\text { AB test for AR(1) (p-val) } \\
\text { AB test for AR(2) (p-val) } \\
\text { Sargan test (p-val) } \\
\text { Hansen test (p-val) }\end{array}$ & $\begin{array}{c}552 \\
0.013\end{array}$ & $\begin{array}{c}552 \\
0.016\end{array}$ & $\begin{array}{c}552 \\
0.021\end{array}$ & $\begin{array}{l}552 \\
0.000 \\
0.627 \\
0.643 \\
0.160\end{array}$ & $\begin{array}{l}552 \\
0.000 \\
0.576 \\
0.155 \\
0.307\end{array}$ & $\begin{array}{l}552 \\
0.000 \\
0.737 \\
0.962 \\
0.331\end{array}$ & $\begin{array}{c}552 \\
0.004\end{array}$ & $\begin{array}{c}552 \\
0.045\end{array}$ & $\begin{array}{c}552 \\
0.046\end{array}$ & $\begin{array}{l}552 \\
0.000 \\
0.701 \\
0.132 \\
0.371\end{array}$ & $\begin{array}{l}552 \\
0.000 \\
0.731 \\
0.107 \\
0.152\end{array}$ & $\begin{array}{l}552 \\
0.000 \\
0.708 \\
0.122 \\
0.332\end{array}$ \\
\hline
\end{tabular}

Source: Authors' calculations.

Note: $\quad \mathrm{AB}=$ Arellano and Bond(1991); $\mathrm{HM}=$ heavy monsoon; $\mathrm{RM}=$ Regular monsoon; $\mathrm{AR}(1)=$ first-order autocovariance in residuals of order 1; $\mathrm{AR}(2)=$ first-order

autocovariance in residuals of order 2. Time and district - origin for specifications (1)-(6) and destination for specification (7)-(12)-fixed effects are included. Robust standard errors in parentheses. Based on Conley (1999) a correction for spatial dependency with a cutoff point of 64 kilometers is applied for OLS specifications. * significant at 10\%, $* *$ at $5 \%, * * *$ at $1 \%$ 
Table 5.2 Descriptive statistics for district-level variables, periods 2000 to 2003 and 2007 to 2010 (districts $=69, n=552$ )

\begin{tabular}{l|ccc}
\hline \hline Variable & Mean & $\begin{array}{c}\text { Standard } \\
\text { deviation }\end{array}$ & $\begin{array}{c}\text { Fisher's } \\
\text { test }\end{array}$ \\
\hline Flood during heavy monsoon (unweighted) & 0.183 & $(0.387)$ & $329^{* * *}$ \\
Drought during heavy monsoon (unweighted) & 0.308 & $(0.462)$ & $443^{* * *}$ \\
Total conflicts per square km & 0.002 & $(0.009)$ & 120 \\
River density (length of river per square km) & 0.171 & $(0.023)$ & $343^{* * *}$ \\
Actual migration outflow rate from district & 0.005 & $(0.007)$ & $358^{* * *}$ \\
Actual migration inflow rate to district & 0.003 & $(0.005)$ & $329^{* * *}$ \\
Aggregate actual net migration rate (cum. 4-year) & & $(0.031)$ & \\
0.005 (weighted by sample size in each district) & & & \\
\hline \hline
\end{tabular}

Source: Authors' calculations.

Note: $\mathrm{km}=$ kilometer; cum $=$ cumulative. ${ }^{* * *}$ significant at $1 \%$.

Table 5.3 presents the results from the first-stage regressions. Predicted migration rates calculated from formula (2) for in-migration (and a similar formula for out-migration) are used as instruments for actual net migration rates. We also provide a just-identified version of the first stage, using the predicted net migration rate as one instrument subtracting the aforementioned two formulas.

Table 5.3 Relationship between predicted and actual migration rates (first stage)

\begin{tabular}{|c|c|c|c|c|}
\hline \multirow{3}{*}{ Dependent variable } & \multicolumn{4}{|c|}{ Actual net migration rate } \\
\hline & \multicolumn{2}{|c|}{$\begin{array}{l}\text { Dynamic } \\
\text { model }\end{array}$} & \multicolumn{2}{|c|}{$\begin{array}{c}\text { OLS } \\
\text { model }\end{array}$} \\
\hline & IV(1) & IV(2) & IV(1) & IV(2) \\
\hline $\begin{array}{l}\text { Predicted net migration rate } \\
\text { (cumulative 4-year) }\end{array}$ & $\begin{array}{l}1.459 * * * \\
(0.533)\end{array}$ & & $\begin{array}{l}2.107 * * * \\
(0.668)\end{array}$ & \\
\hline $\begin{array}{l}\text { Predicted out migration rate } \\
\text { (cumulative } 4 \text {-year) }\end{array}$ & & $\begin{array}{c}-0.580 * * \\
(0.241)\end{array}$ & & $\begin{array}{l}-4.829 \\
(5.123)\end{array}$ \\
\hline $\begin{array}{l}\text { Predicted in migration rate } \\
\text { (cumulative } 4 \text {-year) }\end{array}$ & & $\begin{array}{l}1.918 * * * \\
(0.672)\end{array}$ & & $\begin{array}{c}2.165 * * \\
(0.862)\end{array}$ \\
\hline Individual age & $\begin{array}{l}-0.00000 \\
(0.000)\end{array}$ & $\begin{array}{c}-0.00001 \\
(0.000)\end{array}$ & $\begin{array}{c}-0.00001 \\
(0.000)\end{array}$ & $\begin{array}{c}-0.00001 \\
(0.000)\end{array}$ \\
\hline Individual male & $\begin{array}{c}0.00008 \\
(0.000)\end{array}$ & $\begin{array}{l}0.0002 \\
(0.000)\end{array}$ & $\begin{array}{l}0.0002 \\
(0.000)\end{array}$ & $\begin{array}{l}0.0002 \\
(0.000)\end{array}$ \\
\hline Individual education years & $\begin{array}{l}-0.0000 \\
(0.000)\end{array}$ & $\begin{array}{c}-0.00002 \\
(0.000)\end{array}$ & $\begin{array}{c}-0.00003 \\
(0.000)\end{array}$ & $\begin{array}{c}-0.00002 \\
(0.000)\end{array}$ \\
\hline Urban & $\begin{array}{c}0.00015 \\
(0.000)\end{array}$ & $\begin{array}{r}0.00017 \\
(0.000)\end{array}$ & $\begin{array}{l}0.00025 \\
(0.000)\end{array}$ & $\begin{array}{c}0.00034 \\
(0.000)\end{array}$ \\
\hline Observations & 24.235 & 24.235 & 24.235 & 24.235 \\
\hline R-Squared & 0.598 & 0.652 & 0.646 & 0.652 \\
\hline Number of districts & 69 & 69 & 69 & 69 \\
\hline F-stat & $58.28 * * *$ & $63.92 * * *$ & $61.67 * * *$ & $64.5^{* * *}$ \\
\hline F-stat on excluded IV & $13.86 * * *$ & $12.53 * * *$ & $23.003 * * *$ & $13.34 * * *$ \\
\hline $\begin{array}{l}\text { Weak identification test }{ }^{a} \\
\text { Stock-Yogo critical values }\end{array}$ & 13.784 & 12.464 & 22.861 & 13.223 \\
\hline 10 percent maximal IV size & 16.380 & 19.930 & 16.380 & 19.930 \\
\hline 15 percent maximal IV size & 8.960 & 11.590 & 8.960 & 11.590 \\
\hline
\end{tabular}

Source: Authors' calculations.

Note: IV = Independent variable; OLS = Ordinary least squares. Time and district fixed effects are included. a The weak identification test provides the Kleibergen-Paap rk Wald F statistic. Standard errors in parentheses are bootstrapped and clustered at the district level. * significant at $10 \%, * *$ at $5 \%,{ }^{* * *}$ at $1 \%$. 
Figure 5.1 maps the predicted and observed net migration rates. Although strongly correlated in areas with major cities, the two maps substantially differ in that the predicted figures capture a subsample of the observed net migration rates. For Kathmandu, actual and predicted net-migration rates are strongly correlated. Actual net migration rates were 0.020 and 0.117 , while predicted net migration rates were 0.023 and 0.064 in 2003 and 2010, respectively. In other cities, such as Nepalganj in the southwestern Banke district (Figure 5.1), the distinction between actual and predicted migration is much larger. The actual net migration rate is 0.046 and 0.010 in contrast to the predicted net migration rate of -0.003 and -0.004 in 2003 and 2010, respectively. The striking differences across predicted and observed net migration rates highlight that the interpretation of our results is not generalizable to any type of migrants in Nepal.

Figure 5.1 Actual and predicted net migration, Nepal 2003 and 2010
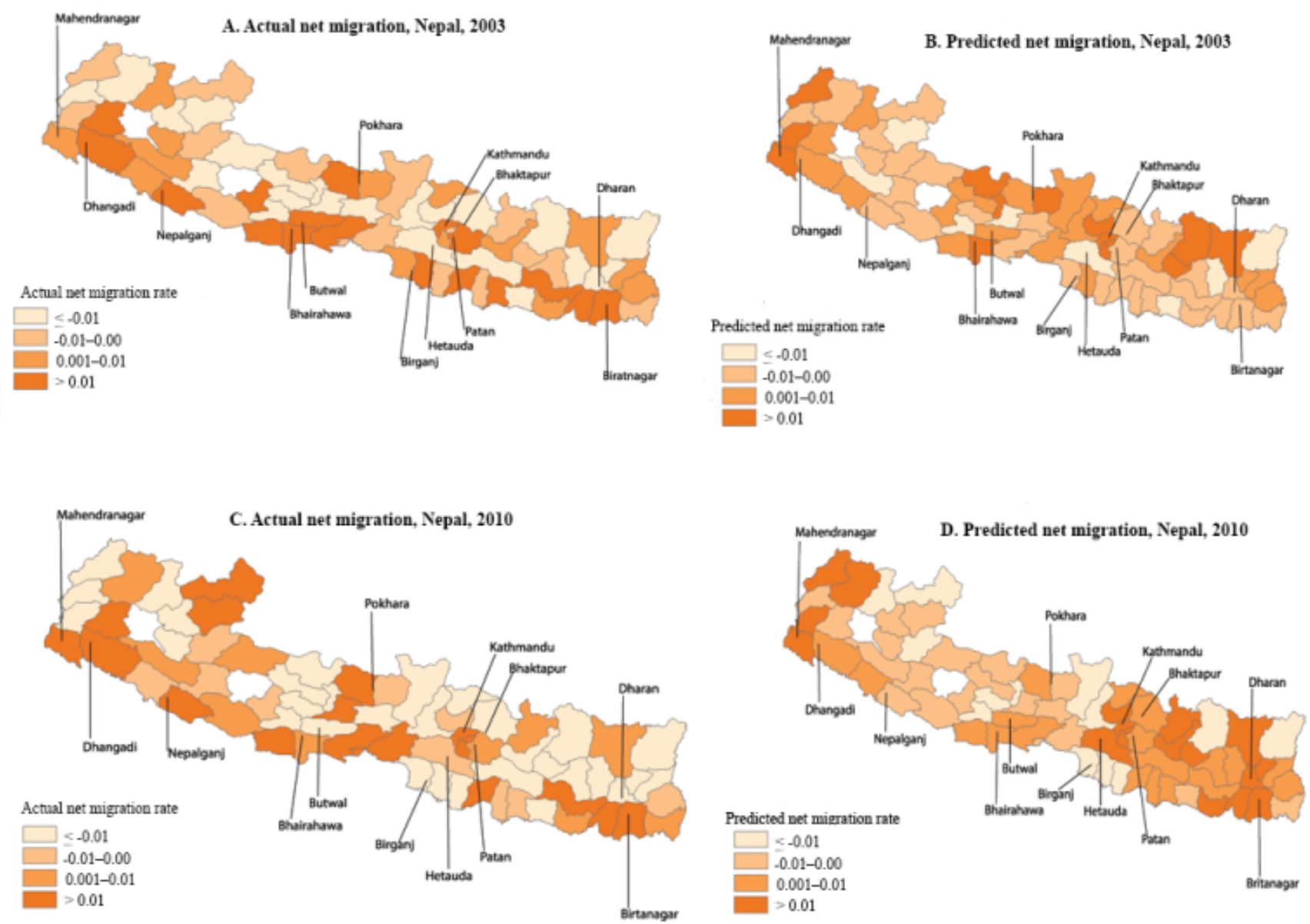

Source: Authors' own representation.

Note: Districts not used are omitted from maps.

\section{Impact of Migration on Hosting Labor Markets}

We now present our estimates of the impact of net migration rates on labor markets outcomes. In Table 5.4 , our dependent variable is the logarithm of monthly real wage, distinguishing between the formal and informal sectors. The two-stage least-squares estimates under just-identified (column 5) or over identified (column 6) equations indicate a strong negative impact in the formal sector. A 1 percent increase in net migration rates would translate into a fall in real wages by about 5 percent. Contrary to the findings of Kleemans and Magruger (2012), the negative impact is found only in the formal sector. These effects are consistent with migrants' being engaged in activities in the formal sector more than nonmigrants. 
Table 5.4 Effect of net migration rate on wages for nonmigrant household heads aged 18-65 (second stage)

\begin{tabular}{|c|c|c|c|c|c|c|c|c|c|}
\hline \multirow[t]{4}{*}{ Dependent variable } & \multicolumn{9}{|c|}{ Log monthly real wages (2010 Nepal rupees) } \\
\hline & OLS & $\operatorname{IV}(1)$ & $\mathrm{IV}(2)$ & OLS & IV(1) & IV(2) & OLS & $\operatorname{IV}(1)$ & $\operatorname{IV}(2)$ \\
\hline & \multicolumn{3}{|c|}{ All } & \multicolumn{3}{|c|}{ Formal sector } & \multicolumn{3}{|c|}{ Informal sector } \\
\hline & $(1)$ & $(2)$ & (3) & $(4)$ & $(5)$ & $(6)$ & $(7)$ & $(8)$ & $(9)$ \\
\hline Net migration rate & -1.6014 & 1.745 & 0.992 & $-5.072 * * *$ & $-4.753 * * *$ & $-5.066 * * *$ & 1.162 & 6.700 & $\overline{5.791}$ \\
\hline (cumulative 4-yr) & $(0.962)$ & $(3.298)$ & $(2.808)$ & $(0.560)$ & $(0.855)$ & $(0.671)$ & $(1.554)$ & $(5.129)$ & $(4.597)$ \\
\hline Individual control & $\mathrm{Y}$ & $\mathrm{Y}$ & $\mathrm{Y}$ & $\mathrm{Y}$ & $\mathrm{Y}$ & $\mathrm{Y}$ & $\mathrm{Y}$ & $\mathrm{Y}$ & $\mathrm{Y}$ \\
\hline Occupation dummies & $\mathrm{Y}$ & $\mathrm{Y}$ & $\mathrm{Y}$ & $\mathrm{Y}$ & Y & Y & $\mathrm{Y}$ & Y & Y \\
\hline Observations & 5,234 & 5,234 & 5,234 & 4,119 & 4,119 & 4,119 & 3,113 & 3,113 & 3,113 \\
\hline R-squared (within) & 0.510 & 0.508 & 0.509 & 0.285 & 0.285 & 0.285 & 0.365 & 0.362 & 0.363 \\
\hline Districts & 69 & 69 & 69 & 67 & 67 & 67 & 69 & 69 & 69 \\
\hline
\end{tabular}

Source: Authors' calculations.

Note: $\quad$ IV = Independent variable; OLS = Ordinary least squares. Time and district fixed effects included. Standard errors, clustered at the district level, in parentheses. * significant at 10\%, ** at 5\%,*** at 1\%. In all subsequent specifications, IV(1) and IV(2) use predicted net migration rates to instrument actual net migration rate, and predicted in- and outmigration rates as separate instruments for actual in- and out-migration rates, respectively.

The formal-sector wage effects for each district are extrapolated from the regression results and presented in Figure 5.2. A 1 percent increase in net migration rates from increased frequency of droughts, floods, and conflict in this part of the world is expected to have profound effects on the economic geography of Nepal. There is quite a bit of variation in the wage effects across space which corresponds to in Figure 5.1, which suffers the most negative consequences.

Figure 5.2 Estimated effects of predicted net migration on formal-sector wages, Nepal 2003 and 2010
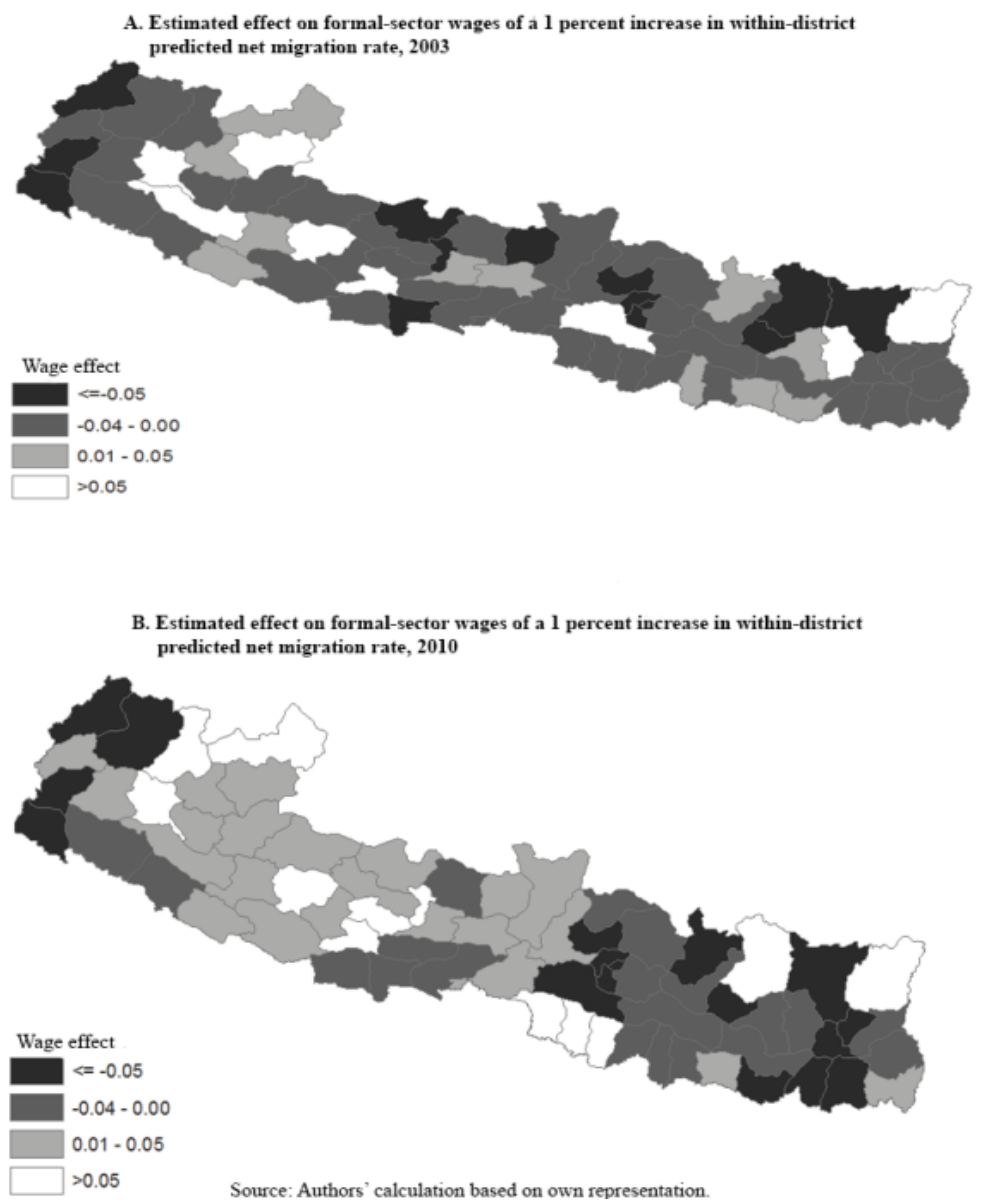

Note: Districts not used are omitted from maps. 
Our descriptive statistics also reveal that the difference between migrants and nonmigrants may be driven by distinctions in skills: in 2010, 46 percent of migrants were considered skilled compared with 18 percent of nonmigrants. It is therefore not surprising to observe that net migration negatively affects the real wages of high-skilled nonmigrants (columns 1-3, Panel A, Table 5.5), in particular in the formal sector where most (relatively) high-skilled migrants are competing (columns 7-9, Panel B, Table 5.5). The magnitude of the wage effect resembles wage losses in the context of labor substitutability among low-skilled workers An Ahe United States (for example, 1-2 percent declines Aound Ay Altonji And Aard 1991 Ar Ottaviano And Peri 2012). Nonetheless, Ahe negative Ampact Aound An Ahe Aormal sector Aor the low-skilled workers (columns 10-12, Panel B, Table A.5) sheds doubt An A mechanism exclusively based on labor substitutability.

Table 5.5 Effect of net migration rate on wages for nonmigrant household heads aged 18-65, by skill (second stage)

\begin{tabular}{|c|c|c|c|c|c|c|}
\hline \multirow[t]{2}{*}{ Dependent variable } & \multicolumn{6}{|c|}{ Log monthly real wages (2010 Nepal rupees) } \\
\hline & OLS & $\operatorname{IV}(1)$ & $\operatorname{IV}(2)$ & OLS & $\operatorname{IV}(1)$ & $\operatorname{IV}(2)$ \\
\hline \multirow[t]{3}{*}{ Panel A } & \multicolumn{6}{|c|}{ All sectors } \\
\hline & \multicolumn{3}{|c|}{ High skill } & \multirow{2}{*}{\multicolumn{3}{|c|}{ Low skill }} \\
\hline & $(1)$ & (2) & (3) & (4) & & $(6)$ \\
\hline $\begin{array}{l}\text { Net migration rate } \\
\text { (cumulative } 4 \text {-year) }\end{array}$ & $\begin{array}{l}-1.940^{*} \\
(1.068)\end{array}$ & $\begin{array}{r}-1.253 \\
(1.453)\end{array}$ & $\begin{array}{r}-1.202 \\
(1.438)\end{array}$ & $\begin{array}{l}-0.6378 \\
(1.133)\end{array}$ & $\begin{array}{c}4.615 \\
(4.638)\end{array}$ & $\begin{array}{c}3.431 \\
(3.961)\end{array}$ \\
\hline Individual control & $\mathrm{Y}$ & $\mathrm{Y}$ & $\mathrm{Y}$ & $\mathrm{Y}$ & $\mathrm{Y}$ & $\mathrm{Y}$ \\
\hline Occupation & Y & $\mathrm{Y}$ & Y & Y & Y & Y \\
\hline Observations & 1,075 & 1,075 & 1,075 & 4,154 & 4,154 & 4,154 \\
\hline R-squared (within) & 0.464 & 0.464 & 0.464 & 0.480 & 0.478 & 0.479 \\
\hline \multirow[t]{3}{*}{ Panel B } & \multicolumn{6}{|c|}{ Formal sector } \\
\hline & \multicolumn{3}{|c|}{ High skill } & \multicolumn{3}{|c|}{ Low skill } \\
\hline & (7) & (8) & $(9)$ & $(10)$ & $(11)$ & $(12)$ \\
\hline $\begin{array}{l}\text { Net migration rate } \\
\text { (cumulative } 4 \text {-year) }\end{array}$ & $\begin{array}{c}-1.675^{* *} \\
(0.705)\end{array}$ & $\begin{array}{l}-1.518^{*} \\
(0.818)\end{array}$ & $\begin{array}{c}-1.593^{* *} \\
(0.790)\end{array}$ & $\begin{array}{c}-5.397 * * * \\
(0.745)\end{array}$ & $\begin{array}{c}-4.655^{* * *} \\
(1.326)\end{array}$ & $\begin{array}{c}-5.376^{* * *} \\
(0.939)\end{array}$ \\
\hline Individual controls & $\mathrm{Y}$ & $\mathrm{Y}$ & $\mathrm{Y}$ & $\mathrm{Y}$ & $\mathrm{Y}$ & $\mathrm{Y}$ \\
\hline Occupation & Y & $\mathrm{Y}$ & $\mathrm{Y}$ & Y & $\mathrm{Y}$ & $\mathrm{Y}$ \\
\hline Observations & 573 & 573 & 573 & 1,530 & 1,530 & 1,530 \\
\hline R-squared (within) & 0.171 & 0.171 & 0.171 & 0.250 & 0.250 & 0.250 \\
\hline Number of districts & 45 & 45 & 45 & 66 & 66 & 66 \\
\hline
\end{tabular}

Source: Authors' calculations.

Note: $\quad$ IV $=$ Independent variable; OLS $=$ Ordinary least squares. High skill refers to those individuals with at least 10 years of education. Time and district fixed effects included. Standard errors, clustered at the district level, iin parentheses. $*$ significant at $10 \%, * *$ at $5 \%$, *** at $1 \%$.

Tables 5.6 and 5.7 point to another source of vulnerability for low-skilled workers. Low-skilled workers face a lower probability of employment (columns 14 and 15, Table 5.6) and a higher probability of unemployment (columns 8 and 9, Table 5.7). Raising net migration by 1 percentage point increases the unemployment of unskilled workers by 1.5 percentage points. A slightly lower (reverse) elasticity is found for employment probability. In turn, employment and unemployment probabilities have the expected sign for skilled workers, although statistically significant for the probability to be unemployed (columns 5 and 6, Table 5.7). Such contrasting results are consistent with a displacement of low-skilled workers out of the labor market. 
Table 5.6 Effect of net migration rate on employment for nonmigrant household heads aged 18-65 (second stage)

\begin{tabular}{|c|c|c|c|c|c|c|c|c|c|}
\hline \multirow[t]{2}{*}{ Dependent variable } & \multicolumn{9}{|c|}{ Employment probability (worked in last 12 months) } \\
\hline & OLS & IV $(1)$ & $\operatorname{IV}(2)$ & OLS & $\operatorname{IV}(1)$ & $\operatorname{IV}(2)$ & OLS & $\operatorname{IV}(1)$ & $\operatorname{IV}(2)$ \\
\hline \multirow[t]{2}{*}{ Panel A } & & All & & \multicolumn{3}{|c|}{ Formal sector } & \multicolumn{3}{|c|}{ Informal sector } \\
\hline & (1) & (2) & (3) & (4) & $(5)$ & $(6)$ & (7) & $(8)$ & (9) \\
\hline Net migration rate & $-0.721 * * *$ & $-0.934 * * *$ & $-0.981 * * *$ & $0.459^{*}$ & 0.594 & 0.725 & $-1.132 * * *$ & $-1.466^{* * *}$ & $-1.630 * * *$ \\
\hline (cumulative 4-year) & $(0.110)$ & $(0.154)$ & $(0.161)$ & $(0.241)$ & $(0.381)$ & $(0.485)$ & $(0.209)$ & $(0.434)$ & $(0.556)$ \\
\hline Individual control & $\mathrm{Y}$ & $\mathrm{Y}$ & $\mathrm{Y}$ & $\mathrm{Y}$ & $\mathrm{Y}$ & $\mathrm{Y}$ & $\mathrm{Y}$ & $\mathrm{Y}$ & $\mathrm{Y}$ \\
\hline Occupation dummies & $\mathrm{Y}$ & $\mathrm{Y}$ & $\mathrm{Y}$ & $\mathrm{Y}$ & Y & $\mathrm{Y}$ & $\mathrm{Y}$ & $\mathrm{Y}$ & $\mathrm{Y}$ \\
\hline Observations & 7,965 & 7,965 & 7,965 & 7,965 & 7,965 & 7,965 & 7,965 & 7,965 & 7,965 \\
\hline R-squared (within) & 0.055 & 0.055 & 0.055 & 0.055 & 0.055 & 0.055 & 0.040 & 0.040 & 0.040 \\
\hline Districts & 69 & 69 & 69 & 69 & 69 & 69 & 69 & 69 & 69 \\
\hline \multirow[t]{2}{*}{ Panel B } & \multicolumn{6}{|c|}{ Low skill } & & & \\
\hline & (10) & (11) & (12) & (13) & (14) & (15) & & & \\
\hline Net migration rate & -0.113 & -0.073 & -0.098 & $-0.710 * * *$ & $-1.031 * * *$ & $-1.096^{* * *}$ & & & \\
\hline (cumulative 4-year) & $(0.170)$ & $(0.189)$ & $(0.173)$ & $(0.163)$ & $(0.212)$ & $(0.217)$ & & & \\
\hline Individual control & $\mathrm{Y}$ & $\mathrm{Y}$ & $\mathrm{Y}$ & $\mathrm{Y}$ & $\mathrm{Y}$ & $\mathrm{Y}$ & & & \\
\hline Occupation dummies & $\mathrm{Y}$ & $\mathrm{Y}$ & $\mathrm{Y}$ & $\mathrm{Y}$ & $\mathrm{Y}$ & $\mathrm{Y}$ & & & \\
\hline Observations & 1,358 & 1,358 & 1,358 & 6,604 & 6,604 & 6,604 & & & \\
\hline R-squared (within) & 0.182 & 0.182 & 0.182 & 0.111 & 0.111 & 0.111 & & & \\
\hline Districts & 64 & 64 & 64 & 69 & 69 & 69 & & & \\
\hline
\end{tabular}

Source: Authors' calculations.

Note: $\quad$ IV $=$ Independent variable; OLS = Ordinary least squares. High skill refers to those individuals with at least 10 years of education Time and district fixed effects included. Standard errors, clustered at the district level, in parentheses. * significant at $10 \%$, $* *$ at $5 \%, * * *$ at $1 \%$

Table 5.7 Effect of net migration rate on unemployment for nonmigrant household heads aged 18-65

\begin{tabular}{|c|c|c|c|c|c|c|c|c|c|}
\hline \multirow[t]{4}{*}{ Dependent variable } & \multicolumn{9}{|c|}{ Unemployment probability (worked in last 12 months) } \\
\hline & OLS & $\operatorname{IV}(1)$ & $\operatorname{IV}(2)$ & OLS & $\operatorname{IV}(1)$ & $\operatorname{IV}(2)$ & OLS & $\operatorname{IV}(1)$ & $\operatorname{IV}(2)$ \\
\hline & \multicolumn{3}{|c|}{ All } & \multicolumn{3}{|c|}{ High skill } & \multicolumn{3}{|c|}{ Low skill } \\
\hline & (1) & (2) & (3) & (4) & $(5)$ & $(6)$ & (7) & (8) & (9) \\
\hline Net migration rate & $1.011 * * *$ & $1.295 * * *$ & $1.372 * * *$ & $0.552 * * *$ & $0.570 * * *$ & $0.574 * * *$ & $1.147 * * *$ & $1.542 * * *$ & $1.675 * * *$ \\
\hline (cumulative 4-year) & $(0.211)$ & $(0.172)$ & $(0.163)$ & $(0.163)$ & $(0.182)$ & $(0.173)$ & $(0.329)$ & $(0.257)$ & $(0.215)$ \\
\hline Individual control & $\mathrm{Y}$ & $\mathrm{Y}$ & $\mathrm{Y}$ & $\mathrm{Y}$ & $\mathrm{Y}$ & $\mathrm{Y}$ & $\mathrm{Y}$ & $\mathrm{Y}$ & $\mathrm{Y}$ \\
\hline Occupation dummies & $\mathrm{Y}$ & $\mathrm{Y}$ & $\mathrm{Y}$ & $\mathrm{Y}$ & $\mathrm{Y}$ & $\mathrm{Y}$ & $\mathrm{Y}$ & $\mathrm{Y}$ & Y \\
\hline Observations & 7,965 & 7,965 & 7,965 & 1,358 & 1,358 & 1,358 & 6,604 & 6,604 & 6,604 \\
\hline R-squared (within) & 0.100 & 0.099 & 0.099 & 0.153 & 0.153 & 1,358 & 0.095 & 0.094 & 0.093 \\
\hline Districts & 69 & 69 & 69 & 64 & 64 & 64 & 69 & 69 & 69 \\
\hline
\end{tabular}

Source: Authors' calculations.

Note: IV = Independent variable; OLS = Ordinary least squares. High skill refers to those individuals with at least 10 years of education. Time and district fixed effects included. Standard errors, clustered at the district level, in parentheses. ${ }^{*}$ significant at $10 \%$, $* *$ at $5 \%, * * *$ at $1 \%$.

\section{Validity of the Instruments}

The identification strategy hinges on two main identifying assumptions: the strength and the exogenous nature of the predicted net migration rates used as instruments. First, the individual t- and F-tests, assuming weak instruments, indicate the instruments are strong predictors of the actual net migration rate (Table 5.3). The Kleibergen Paap rk Wald F statistics range between 12 and 14 for our preferred dynamic 
specification, which exceeds the Stock and Yogo (2005) critical values with 15 percent absolute bias. ${ }^{14}$ We also note that the predicted net migration rates positively affect observed net migration rates, which is reassuring given that just-identified estimates are median-unbiased.

Second, it is intuitively plausible that the predicted migration rates affect labor market outcomes only through observed migration rates. In Section 4, we rationalize the focus of the analysis at the district level and the use of lagged environmental and political shocks in predicting migration rates to satisfy the exclusion restriction. One possible violation of the exclusion restriction would nonetheless result if (weather and political) shocks in neighboring districts have direct impacts on labor market outcomes. ${ }^{15}$ We therefore test the stability of our coefficients of interest in the second-stage regressions to the inclusion of spatially lagged variables. The spatially lagged variables are obtained by multiplying the variables used to predict migration in equation (3) with a distance-based spatial matrix that weights the value of each variable for one district by the inverses of the Euclidean distances to the geographical centers of all other districts (Anselin 2002). The inclusion of these spatially lagged variables does not alter substantially the magnitude of the impact of migration on labor market outcomes. ${ }^{16}$ We can therefore rule out the possible threat to our identification strategy that would result from spatial spillovers from environmental and political shocks.

\section{Reflections on the Role of the Informal Labor Market in Absorbing Displaced Workers}

The seemingly contrasting results between employment and wage outcomes deserve further investigation. The displacement of low-skilled workers out of the labor market cannot be explained by the labor substitution mechanism. First, immigration may change demand in ways differentially affecting formaland informal-sector workers (Altonji and Card 1991). For example, a growing literature demonstrates immigration influences prices and consumption composition (Saiz 2003, 2007; Lach 2007; Cortes 2008). Second, although our findings are somewhat consistent with the predictions of Kleemans and Magruder (2012), our informal-sector results suggest binding constraints preclude the absorption of workers (for example, registration requirements may prevent the entry of new enterprises, or credit constraints prevent enterprise expansion). We reflect on the plausibility of these hypotheses descriptively. ${ }^{17}$

We first examine whether native workers change their consumption patterns in response to migrant flows. It is important to note that the general equilibrium framework developed by Altonji and Card (1991) accounts for the increase in the demand for goods caused by the shift in the population from migration. We explore an additional effect on labor demand, which is through shifts in preferences for goods. If the purchasing power parity of workers declines with immigration, then we might expect to observe changes in consumption patterns. While total consumption remains unaffected by migration, native workers reduce the share of service goods consumed in exchange for other nonfood essentials (Table 5.8). These compositional changes in demand do not explain labor market exits in the informal sector, but they do offer one explanation for why formal-sector workers are at most risk. A greater share of formal-sector workers are engaged in the service sector, in which services are likely to have a higher elasticity of demand.

\footnotetext{
14 The F statistics on excluded IV is also above the rule-of-thumb of 10 provided by Stock and Yogo (2005). We also note that when using the predicted out-migration and in-migration rates as separate instruments, the Hansen $J$ test features a p-value above 0.100. It should be noted that the two instruments are similar in nature and the test assumes that at least one instrument is valid.

15 Past migration in equation (3) may also be endogenous. Our results are similar when past migration is omitted and the instruments are constructed using an OLS estimation (as shown in columns 1-3 and 7-9 in Table 5.1). The robustness of the two-stage estimates is provided in Tables A.1 and A.2 in the appendix.

${ }^{16}$ Results are provided in Table A.3. There is only one exception : the impact on wages for the low-skilled workers appears to be positive when spatially lagged variables are included. However, when restricted to the formal sector, we found a negative impact, similar to the one found in Table 5.5 (columns 11-12).

17 These hypotheses are by no means exhaustive. The skilled may be differentially affected if migration affects innovation and technology boosting their marginal productivity (Kerr 2013). Additionally, from a worker's perspective, the returns to his skills or education in the informal sector may be lower than his reservation wage, rendering unemployment more desirable than employment in the informal sector. Although testing the role of migration in innovation is beyond the scope of the paper, we find no descriptive evidence to support the reservation wage argument when comparing the returns on education across sectors in simple Mincerian wage regressions (Table A.4 in the appendix).
} 
Table 5.8 Effect of net migration rate on nonmigrant household expenditure patterns

\begin{tabular}{|c|c|c|c|c|c|c|}
\hline & OLS & IV $(1)$ & $\mathrm{IV}(2)$ & OLS & IV(1) & $\operatorname{IV}(2)$ \\
\hline \multirow[t]{2}{*}{ Panel A } & \multicolumn{3}{|c|}{$\begin{array}{c}\text { Log per capita total } \\
\text { expenditures (real } 2010 \text { rupees) }\end{array}$} & \multicolumn{3}{|c|}{$\begin{array}{l}\text { Share food expenditures } \\
\text { (real } 2010 \text { rupeees) }\end{array}$} \\
\hline & (1) & (2) & (3) & (4) & (5) & (6) \\
\hline $\begin{array}{l}\text { Net migration rate } \\
\text { (cumulative } 4 \text {-year) }\end{array}$ & $\begin{array}{l}-0.549 \\
(0.436)\end{array}$ & $\begin{array}{l}1.133 \\
(1.504)\end{array}$ & $\begin{array}{l}1.105 \\
(1.539)\end{array}$ & $\begin{array}{c}0.003 \\
(0.146)\end{array}$ & $\begin{array}{c}0.031 \\
(0.163)\end{array}$ & $\begin{array}{c}0.016 \\
(0.167)\end{array}$ \\
\hline Individual control & $\mathrm{Y}$ & $\mathrm{Y}$ & $\mathrm{Y}$ & $\mathrm{Y}$ & $\mathrm{Y}$ & $\mathrm{Y}$ \\
\hline Occupation & $\mathrm{Y}$ & $\mathrm{Y}$ & $\mathrm{Y}$ & $\mathrm{Y}$ & $\mathrm{Y}$ & $\mathrm{Y}$ \\
\hline dummies & 7,965 & 7,965 & 7,965 & 7,965 & 7,965 & 7,965 \\
\hline Observations & 0.449 & 0.447 & 0.447 & 0.242 & 0.242 & 0.242 \\
\hline R-squared (within) & 69 & 69 & 69 & 69 & 69 & 69 \\
\hline Number of districts & $\overline{\overline{\text { OLS }}}$ & $\overline{\overline{\text { IV(1) }}}$ & IV(2) & $\overline{\text { OLS }}$ & IV(1) & IV(2) \\
\hline \multirow[t]{2}{*}{ Panel B } & \multicolumn{3}{|c|}{$\begin{array}{l}\text { Share nonfood expenditures } \\
\text { excl. services (real } 2010 \text { rupees) }\end{array}$} & \multicolumn{3}{|c|}{$\begin{array}{l}\text { Share services expenditure } \\
\text { (real } 2010 \text { rupees) }\end{array}$} \\
\hline & (7) & (8) & (9) & (10) & (11) & (12) \\
\hline $\begin{array}{l}\text { Net migration rate } \\
\text { (cumulative } 4 \text {-year) }\end{array}$ & $\begin{array}{c}0.555^{* * * *} \\
(0.117)\end{array}$ & $\begin{array}{c}0.855^{* * *} \\
(0.188)\end{array}$ & $\begin{array}{c}0.879 * * * \\
(0.191)\end{array}$ & $\begin{array}{c}-0.558^{* *} \\
(0.225)\end{array}$ & $\begin{array}{c}-0.886^{* * * *} \\
(0.147)\end{array}$ & $\begin{array}{c}-0.895^{* * * *} \\
(0.126)\end{array}$ \\
\hline Individual control & $\mathrm{Y}$ & $\mathrm{Y}$ & $\mathrm{Y}$ & $\mathrm{Y}$ & $\mathrm{Y}$ & $\mathrm{Y}$ \\
\hline Occupation & $\mathrm{Y}$ & Y & $\mathrm{Y}$ & $\mathrm{Y}$ & $\mathrm{Y}$ & $\mathrm{Y}$ \\
\hline dummies & 7,965 & 7,965 & 7,965 & 7,965 & 7,965 & 7,965 \\
\hline Observations & 0.356 & 0.355 & 0.354 & 0.065 & 0.064 & 0.063 \\
\hline R-squared (within) & 69 & 69 & 69 & 69 & 69 & 69 \\
\hline
\end{tabular}

Source: Authors'calculations.

Note: IV = Independent variable; OLS = Ordinary least squares. High skill refers to those individuals with at least 10 years of education. Time and district fixed effects included. Standard errors, clustered at the district level, in parentheses. ${ }^{*}$ significant at $10 \%,{ }^{* *}$ at $5 \%,{ }^{* *}$ at $1 \%$.

We next assess how constraints on the creation and expansion of enterprises may affect the ability of the informal sector to absorb displaced workers.of the informal sector to absorb displaced workers. Descriptive statistics indicate that the majority of enterprises are financed through households' own savings (approximately 40 percent) (Table 5.9). Only a small percentage of enterprises tried to obtain a loan to operate or expand their business (23 percent in 2010) and fewer complained of unsuccessful attempts ( 3 percent). Overall, the environment for hired labor is low (for example, only 17 percent in 2010). Informal enterprises are more inclined to hire workers and a significantly greater number of workers per enterprise. The absence of financial capital may discourage enterprises in the informal sector from expanding or entrepreneurs from creating start-ups. 
Table 5.9 Nonmigrant household financial and capacity constraints of enterprises (own enterprise), weighted, 2003 and 2010

\begin{tabular}{|c|c|c|c|c|c|c|}
\hline \multirow[t]{2}{*}{ Variable } & \multirow{2}{*}{$\begin{array}{c}2003 \\
\text { All } \\
(n=865)\end{array}$} & \multirow{2}{*}{$\begin{array}{c}2010 \\
\text { All } \\
(n=1,854)\end{array}$} & \multicolumn{2}{|c|}{2003} & \multicolumn{2}{|c|}{2010} \\
\hline & & & $\begin{array}{c}\text { Low } \\
\text { skill } \\
(n=695)\end{array}$ & $\begin{array}{c}\text { High } \\
\text { skill } \\
(n=170)\end{array}$ & $\begin{array}{c}\text { Low } \\
\text { skill } \\
(n=1,469)\end{array}$ & $\begin{array}{c}\text { High } \\
\text { skill } \\
(n=385)\end{array}$ \\
\hline $\begin{array}{l}\text { Is the enterprise registered } \\
\text { with the govermnent? (yes) }\end{array}$ & $\begin{array}{c}0.20 \\
(0.40)\end{array}$ & $\begin{array}{c}0.21 \\
(0.41)\end{array}$ & $\begin{array}{c}0.15 \\
(0.35)\end{array}$ & $\begin{array}{c}0.54 \\
(0.50)\end{array}$ & $\begin{array}{c}0.15 \\
(0.36)\end{array}$ & $\begin{array}{c}0.48 \\
(0.50)\end{array}$ \\
\hline \multicolumn{7}{|c|}{ What was the main source of money for setting up the enterprise? } \\
\hline Didn’t need any money & $\begin{array}{c}0.30 \\
(0.46)\end{array}$ & $\begin{array}{c}0.33 \\
(0.47)\end{array}$ & $\begin{array}{c}0.31 \\
(0.46)\end{array}$ & $\begin{array}{c}0.21 \\
(0.41)\end{array}$ & $\begin{array}{c}0.35 \\
(0.48)\end{array}$ & $\begin{array}{c}0.20 \\
(0.40)\end{array}$ \\
\hline Own savings & $\begin{array}{c}0.41 \\
(0.49)\end{array}$ & $\begin{array}{c}0.37 \\
(0.48)\end{array}$ & $\begin{array}{c}0.39 \\
(0.49)\end{array}$ & $\begin{array}{c}0.53 \\
(0.50)\end{array}$ & $\begin{array}{c}0.37 \\
(0.48)\end{array}$ & $\begin{array}{c}0.41 \\
(0.49)\end{array}$ \\
\hline Relatives or friends & $\begin{array}{c}0.14 \\
(0.35)\end{array}$ & $\begin{array}{c}0.13 \\
(0.34)\end{array}$ & $\begin{array}{c}0.15 \\
(0.36)\end{array}$ & $\begin{array}{c}0.10 \\
(0.30)\end{array}$ & $\begin{array}{c}0.13 \\
(0.34)\end{array}$ & $\begin{array}{l}0.16 \\
(0.37)\end{array}$ \\
\hline $\begin{array}{l}\text { Bank (agricultural, } \\
\text { commercial, Grameen type) }\end{array}$ & $\begin{array}{c}0.07 \\
(0.26)\end{array}$ & $\begin{array}{c}0.06 \\
(0.25)\end{array}$ & $\begin{array}{c}0.07 \\
(0.26)\end{array}$ & $\begin{array}{c}0.07 \\
(0.26)\end{array}$ & $\begin{array}{c}0.05 \\
(0.23)\end{array}$ & $\begin{array}{c}0.11 \\
(0.31)\end{array}$ \\
\hline Other financial institution & $\begin{array}{c}0.01 \\
(0.12)\end{array}$ & $\begin{array}{c}0.04 \\
(0.20)\end{array}$ & $\begin{array}{c}0.01 \\
(0.12)\end{array}$ & $\begin{array}{c}0.01 \\
(0.12)\end{array}$ & $\begin{array}{c}0.03 \\
(0.18)\end{array}$ & $\begin{array}{c}0.08 \\
(0.27)\end{array}$ \\
\hline Other & $\begin{array}{c}0.07 \\
(0.25) \\
\end{array}$ & $\begin{array}{c}0.06 \\
(0.25) \\
\end{array}$ & $\begin{array}{c}0.07 \\
(0.25) \\
\end{array}$ & $\begin{array}{c}0.07 \\
(0.25)\end{array}$ & $\begin{array}{c}0.07 \\
(0.25) \\
\end{array}$ & $\begin{array}{c}0.05 \\
(0.21)\end{array}$ \\
\hline \multicolumn{7}{|c|}{ Have you tried to borrow money to operate or expand your business in the past 12 months? (relative to no) } \\
\hline Yes, successfully & $\begin{array}{c}0.20 \\
(0.40)\end{array}$ & $\begin{array}{c}0.23 \\
(0.42)\end{array}$ & $\begin{array}{c}0.20 \\
(0.40)\end{array}$ & $\begin{array}{c}0.18 \\
(0.39)\end{array}$ & $\begin{array}{c}0.22 \\
(0.41)\end{array}$ & $\begin{array}{c}0.31 \\
(0.47)\end{array}$ \\
\hline Yes, unsuccessfully & $\begin{array}{c}0.04 \\
(0.19) \\
\end{array}$ & $\begin{array}{c}0.03 \\
(0.17) \\
\end{array}$ & $\begin{array}{c}0.04 \\
(0.19) \\
\end{array}$ & $\begin{array}{c}0.03 \\
(0.17) \\
\end{array}$ & $\begin{array}{c}0.03 \\
(0.17) \\
\end{array}$ & $\begin{array}{c}0.04 \\
(0.20) \\
\end{array}$ \\
\hline $\begin{array}{l}\text { Did you hire anyone over } \\
\text { the past } 12 \text { months? (yes) }\end{array}$ & $\begin{array}{c}0.13 \\
(0.34)\end{array}$ & $\begin{array}{c}0.17 \\
(0.38)\end{array}$ & $\begin{array}{c}0.11 \\
(0.31)\end{array}$ & $\begin{array}{c}0.30 \\
(0.46)\end{array}$ & $\begin{array}{c}0.14 \\
(0.34)\end{array}$ & $\begin{array}{c}0.35 \\
(0.49)\end{array}$ \\
\hline \multicolumn{7}{|c|}{ How many workers do you normally hire during a month when the enterprise is operating? } \\
\hline ( | hired in last 12 months) & $\begin{array}{c}8.88 \\
(32.10)\end{array}$ & $\begin{array}{c}9.98 \\
(38.60)\end{array}$ & $\begin{array}{c}4.99 \\
(20.60)\end{array}$ & $\begin{array}{c}17.80 \\
(48.20)\end{array}$ & $\begin{array}{r}11.00 \\
(42.80)\end{array}$ & $\begin{array}{c}7.84 \\
(28.40)\end{array}$ \\
\hline \multicolumn{7}{|c|}{ What problems, if any, do you have in running your business? } \\
\hline No major problem & $\begin{array}{c}0.35 \\
(0.48)\end{array}$ & $\begin{array}{c}0.49 \\
(0.50)\end{array}$ & $\begin{array}{c}0.36 \\
(0.48)\end{array}$ & $\begin{array}{c}0.30 \\
(0.46)\end{array}$ & $\begin{array}{c}0.51 \\
(0.50)\end{array}$ & $\begin{array}{c}0.38 \\
(0.49)\end{array}$ \\
\hline Caiptal or credit problem & $\begin{array}{c}0.15 \\
(0.36)\end{array}$ & $\begin{array}{c}0.13 \\
(0.34)\end{array}$ & $\begin{array}{c}0.15 \\
(0.35)\end{array}$ & $\begin{array}{c}0.22 \\
(0.41)\end{array}$ & $\begin{array}{c}0.13 \\
(0.33)\end{array}$ & $\begin{array}{c}0.16 \\
(0.36)\end{array}$ \\
\hline Lack of customers & $\begin{array}{c}0.31 \\
(0.46)\end{array}$ & $\begin{array}{c}0.14 \\
(0.34)\end{array}$ & $\begin{array}{c}0.32 \\
(0.47)\end{array}$ & $\begin{array}{c}0.24 \\
(0.43)\end{array}$ & $\begin{array}{c}0.13 \\
(0.34)\end{array}$ & $\begin{array}{c}0.17 \\
(0.37)\end{array}$ \\
\hline Other & $\begin{array}{c}0.18 \\
(0.39)\end{array}$ & $\begin{array}{c}0.25 \\
(0.43)\end{array}$ & $\begin{array}{c}0.17 \\
(0.38)\end{array}$ & $\begin{array}{c}0.25 \\
(0.44)\end{array}$ & $\begin{array}{c}0.23 \\
(0.42)\end{array}$ & $\begin{array}{c}0.30 \\
(0.46)\end{array}$ \\
\hline
\end{tabular}

Source: Authors' calculations. 


\section{CONCLUSION}

We employ the Boustan, Fishback and Kantor (2010) multi-stage procedure to identify the effects of environmental migration on the labor markets of hosting communities. We modify these authors' procedure for constructing the instrumental variables to incorporate additional variables relevant to our setting (such as conflict exposure), district and time fixed effects, and a dynamic component. We show the dynamic model is preferred to the standard OLS accounting for spatial and time correlation (Conley 1999). Inferences based on the dynamic model suggest droughts and floods are equally crucial determinants of migration as auxiliary factors, proxied by lagged migration. Predictions from the dynamic model are used to construct instruments for net migration rates in the second stage.

Our second-stage regressions indicate wage losses are slightly larger than those observed in the United States and elsewhere (4.8 percent). Labor substitution is imperfect in the Nepal case inasmuch as migrants appear more skilled than the average native worker in hosting communities. The demand for labor in the formal sector also appears binding in the short term following earlier work in Indonesia (Kleemans and Magruder 2012). Imperfect substitution coupled with fixed labor demand in the formal sector may partially explain why wage losses are more pronounced here than in other settings.

Although migrants are positively selected, as in Indonesia, we find informal-sector employment (not wages) is negatively affected. The wages of the informal sector adjust due to the exit of workers from the labor market. Migration appears to change consumption patterns by reducing the share of service goods consumed. Service goods may have a higher elasticity of demand. Furthermore, formal-sector workers are at greater risk than informal-sector workers since a greater share are employed in the service sector. The informal sector's ability to absorb excess labor may also be limited by opportunities to access financial capital in Nepal to support new enterprises or encourage older enterprises to grow. Such descriptive evidence suggests the provision of grants to support enterprises following periods of disasters may foster resilience in hosting economies to forced migration (de Mel, McKenzie, and Woodruff 2012). 


\section{APPENDIX: SUPPLEMENTARY TABLES AND FIGURES}

Figure A.1 Droughts in Nepal, cumulative over four years, 2003 versus 2010
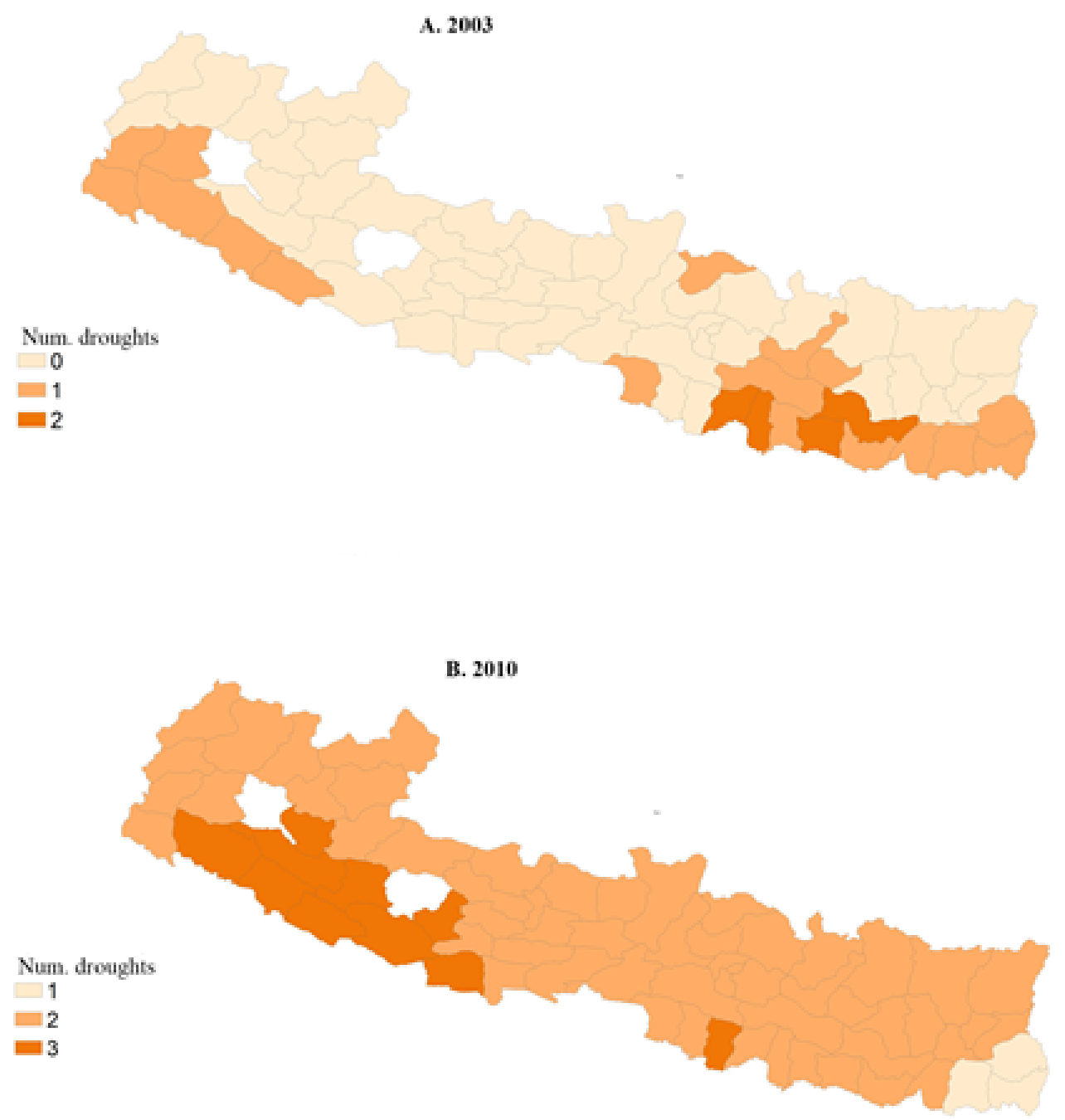

Source: Authors' own representation.

Note: Districts not used are omitted from maps. 
Figure A.2 Conflicts in Nepal, cumulative over previous four years, 2003 versus 2010
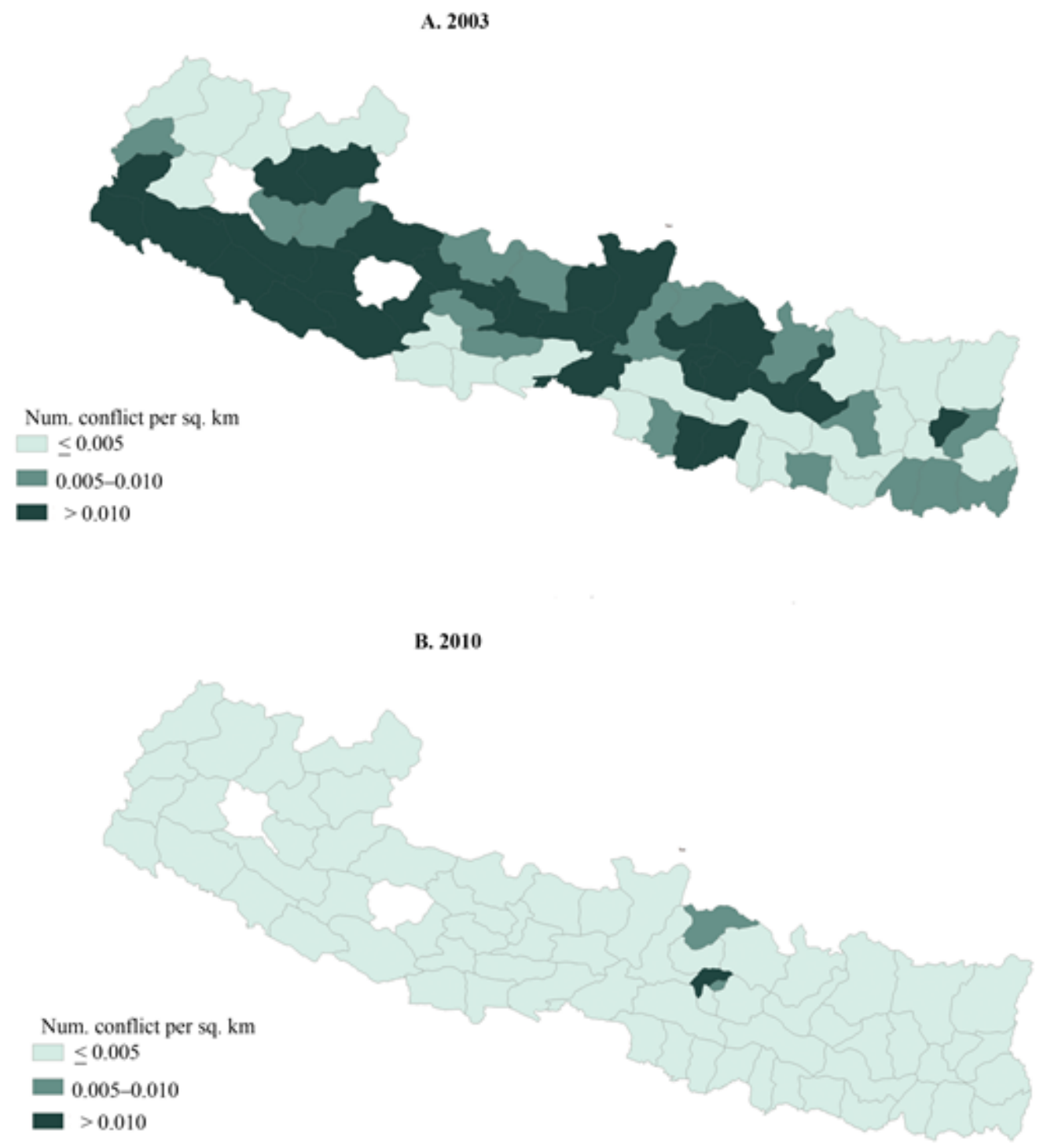

Source: Authors' own representation.

Note: Districts not used are omitted from maps. 
Table A.1 Effect of net migration rate on wages using alternate instruments derived from adjusted OLS method for nonmigrant household heads aged 18-65 (second stage)

\begin{tabular}{l|cc|ccc|cc}
\hline \hline Dependent variable & \multicolumn{6}{|c}{ Log monthly real wages (2010 Nepal rupees) } \\
& IV(1) & IV(2) & IV(1) & IV(2) & IV(1) & IV(2) \\
\hline & \multicolumn{3}{|c|}{ All } & \multicolumn{2}{c}{ Formal sector } & \multicolumn{2}{c}{ Informal sector } \\
& $(1)$ & $(2)$ & $(3)$ & $(4)$ & $(5)$ & $(6)$ \\
\hline \hline Net migration rate & 0.290 & 0.126 & $-5.2797^{* * *}$ & $-5.3236^{* * *}$ & 4.6988 & 4.5644 \\
(cumulative 4-year) & $(2.395)$ & $(2.303)$ & $(0.603)$ & $(0.583)$ & $(4.021)$ & $(3.945)$ \\
\hline Individual control & $\mathrm{Y}$ & $\mathrm{Y}$ & $\mathrm{Y}$ & $\mathrm{Y}$ & $\mathrm{Y}$ & $\mathrm{Y}$ \\
Occupation dummies & $\mathrm{Y}$ & $\mathrm{Y}$ & $\mathrm{Y}$ & $\mathrm{Y}$ & $\mathrm{Y}$ & $\mathrm{Y}$ \\
Observations & 5,234 & 5,234 & 2,119 & 2,119 & 3,113 & 3,113 \\
R-squared (within) & 0.509 & 0.509 & 0.285 & 0.285 & 0.364 & 0.364 \\
Number of districts & 69 & 69 & 67 & 67 & 69 & 69 \\
\hline \hline
\end{tabular}

Source: Authors' calculations.

Note $\quad$ IV = Independent variable; OLS = Ordinary least squares. Time and district (origin for specifications (1)-(6) and destination for specification (7)-(12)). Robust standard errors in parentheses. Based on Conley (1999) a correction for spatial dependency with a cut-off point of 64 kilometers is applied for OLS specifications. $*$ significant at $10 \%, * *$ at $5 \%, * * *$ at $1 \%$.

Table A.2 Effect of net migration rate on wages using alternate instruments derived from adjusted OLS method for nonmigrant household heads aged 18-65, by skill (second stage)

\begin{tabular}{|c|c|c|c|c|}
\hline \multirow{2}{*}{ Dependent variable } & \multicolumn{4}{|c|}{ Log monthly real wages (2010 Nepal rupees) } \\
\hline & $\operatorname{IV}(1)$ & $\operatorname{IV}(2)$ & $\operatorname{IV}(1)$ & $\operatorname{IV}(2)$ \\
\hline \multirow[t]{3}{*}{ Panel A } & \multicolumn{4}{|c|}{ All sectors } \\
\hline & \multicolumn{2}{|c|}{ High skill } & \multicolumn{2}{|c|}{ Low skill } \\
\hline & (1) & $(2)$ & (3) & (4) \\
\hline $\begin{array}{l}\text { Net migration rate } \\
\text { (cumulative } 4 \text {-year) }\end{array}$ & $\begin{array}{l}-1.444 \\
(1.368)\end{array}$ & $\begin{array}{l}-1.794 \\
(1.229)\end{array}$ & $\begin{array}{c}2.403 \\
(3.405)\end{array}$ & $\begin{array}{c}2.309 \\
(3.359)\end{array}$ \\
\hline Individual control & $\mathrm{Y}$ & $\mathrm{Y}$ & $\mathrm{Y}$ & $\mathrm{Y}$ \\
\hline Occupation dummies & $\mathrm{Y}$ & Y & $\mathrm{Y}$ & $\mathrm{Y}$ \\
\hline Observations & 1,075 & 1,075 & 4,154 & 4,154 \\
\hline R-squared (within) & 0.464 & 0.464 & 0.479 & 0.480 \\
\hline Number of districts & 60 & 60 & 69 & 69 \\
\hline \multirow[t]{3}{*}{ Panel B } & \multicolumn{4}{|c|}{ Formal sector } \\
\hline & \multicolumn{2}{|c|}{ High skill } & \multicolumn{2}{|c|}{ Low skill } \\
\hline & (5) & (6) & (7) & (8) \\
\hline $\begin{array}{l}\text { Net migration rate } \\
\text { (cumulative 4-year) }\end{array}$ & $\begin{array}{c}-1.7355 * * \\
(0.807) \\
\end{array}$ & $\begin{array}{c}-1.7758 * * \\
(0.808) \\
\end{array}$ & $\begin{array}{c}-5.8440 * * * \\
(0.828)\end{array}$ & $\begin{array}{c}-5.9253 * * * \\
(0.803)\end{array}$ \\
\hline Individual control & $\mathrm{Y}$ & $\mathrm{Y}$ & $\mathrm{Y}$ & $\mathrm{Y}$ \\
\hline Occupation dummies & Y & $\mathrm{Y}$ & $\mathrm{Y}$ & $\mathrm{Y}$ \\
\hline Observations & 573 & 573 & 1,530 & 1,530 \\
\hline R-squared (within) & 0.171 & 0.171 & 0.250 & 0.250 \\
\hline Number of districts & 45 & 45 & 66 & 66 \\
\hline
\end{tabular}

Source: Authors' calculations.

Note: $\quad$ IV $=$ Independent variable; OLS $=$ Ordinary least squares. High skill refers to those individuals with at least 10 years of education. Time and district fixed effects included. Standard errors clustered at the district level, in parentheses . ${ }^{*}$ significant at $10 \%, * *$ at $5 \%, * * *$ at $1 \%$. 
Table A.3 Testing exclusion restrictions, including spatially lagged weather shock and climate variables in own district (only net-migration rate coefficients and main outcomes reported)

\begin{tabular}{|c|c|c|c|c|c|c|}
\hline Variable & $\mathrm{IV}(1)$ & $\operatorname{IV}(2)$ & IV(1) & $\mathrm{IV}(2)$ & IV(1) & $\mathrm{IV}(2)$ \\
\hline \multirow[t]{3}{*}{ Panel A } & \multicolumn{6}{|c|}{ Log monthly real wage (2010 Nepal rupees) } \\
\hline & \multicolumn{2}{|c|}{ Formal } & \multicolumn{2}{|c|}{ High skill } & \multicolumn{2}{|c|}{ Low skill } \\
\hline & (1) & (2) & $(3)$ & (4) & $(5)$ & $(6)$ \\
\hline $\begin{array}{l}\text { Net migration rate } \\
\text { (cumulative } 4 \text {-year) }\end{array}$ & $\begin{array}{l}-4.005^{*} \\
(2.209)\end{array}$ & $\begin{array}{c}-4.107 * * \\
(2.041)\end{array}$ & $\begin{array}{l}-7.070 \\
(8.189)\end{array}$ & $\begin{array}{l}-4.136 \\
(9.021)\end{array}$ & $\begin{array}{c}18.839 * * * \\
(6.931)\end{array}$ & $\begin{array}{c}19.976 * * * \\
(7.142)\end{array}$ \\
\hline Observations & 2,120 & 2,120 & 1,075 & 1,075 & 4,154 & 4,154 \\
\hline R-squared & 0.219 & 0.219 & 0.112 & 0.112 & 0.114 & 0.113 \\
\hline Number of districts & 67 & 67 & 60 & 60 & 69 & 69 \\
\hline \multirow[t]{3}{*}{ Panel B } & \multicolumn{6}{|c|}{ Employed (worked in last 12 months) } \\
\hline & \multicolumn{2}{|c|}{ Formal sector } & \multicolumn{2}{|c|}{ High skill } & \multicolumn{2}{|c|}{ Low skill } \\
\hline & (7) & $(8)$ & $(9)$ & $(10)$ & (11) & (12) \\
\hline $\begin{array}{l}\text { Net migration rate } \\
\text { (cumulative } 4 \text {-year) }\end{array}$ & $\begin{array}{l}1.240 * \\
(0.739)\end{array}$ & $\begin{array}{l}1.497 * \\
(0.829)\end{array}$ & $\begin{array}{l}-1.668^{*} \\
(0.916)\end{array}$ & $\begin{array}{l}-1.551 * \\
(0.890)\end{array}$ & $\begin{array}{c}-0.956 * * \\
(0.377)\end{array}$ & $\begin{array}{c}-1.008 * * * \\
(0.380)\end{array}$ \\
\hline Observations & 7,967 & 7,967 & 1,358 & 1,358 & 6,604 & 6,604 \\
\hline R-squared & 0.055 & 0.055 & 0.088 & 0.088 & 0.090 & 0.090 \\
\hline Number of districts & 69 & 69 & 64 & 64 & 69 & 69 \\
\hline \multirow[t]{3}{*}{ Panel C } & \multicolumn{6}{|c|}{ Unemployed (worked in last 12 months) } \\
\hline & \multicolumn{2}{|c|}{ All } & \multicolumn{2}{|c|}{ High skill } & \multicolumn{2}{|c|}{ Low skill } \\
\hline & (13) & (14) & $(15)$ & $(16)$ & (17) & (18) \\
\hline $\begin{array}{l}\text { Net migration rate } \\
\text { (cumulative 4-year) }\end{array}$ & $\begin{array}{c}1.319 * * * \\
(0.363)\end{array}$ & $\begin{array}{c}1.383 * * * \\
(0.378)\end{array}$ & $\begin{array}{l}1.950 * * \\
(0.850)\end{array}$ & $\begin{array}{l}1.860 * * \\
(0.872)\end{array}$ & $\begin{array}{l}1.305 * * * \\
(0.395)\end{array}$ & $\begin{array}{c}1.381 * * * \\
(0.406)\end{array}$ \\
\hline Observations & 7,965 & 7,965 & 1,358 & 1,358 & 6,604 & 6,604 \\
\hline R-squared & 0.077 & 0.077 & 0.103 & 0.103 & 0.079 & 0.078 \\
\hline \multirow[t]{2}{*}{ Number of districts } & 69 & 69 & 64 & 64 & 69 & 69 \\
\hline & \multicolumn{6}{|c|}{ Included in Panels A, B, and C } \\
\hline Spatially lagged variables & Y & $\mathrm{Y}$ & $\mathrm{Y}$ & $\mathrm{Y}$ & $\mathrm{Y}$ & Y \\
\hline HH head controls & $\mathrm{Y}$ & $\mathrm{Y}$ & $\mathrm{Y}$ & $\mathrm{Y}$ & $\mathrm{Y}$ & $\mathrm{Y}$ \\
\hline
\end{tabular}

Source: Authors' calculations.

Note: $\quad$ IV $=$ Independent variable; OLS $=$ Ordinary least squares, $\mathrm{HH}=$ Household. High skill refers to those individuals with at least 10 years of education. Time and district fixed effects included. Standard errors clustered at the district level, in parentheses. $*$ significant at $10 \%, * *$ at $5 \%, * * *$ at $1 \%$. Spatially lagged variables include the spatially lagged versions of all weather and conflict variables used in Table 5.1.

Table A.4a Relationship between skill and wages for nonmigrant household heads, aged 18-65

\begin{tabular}{|c|c|c|c|c|c|c|}
\hline \multirow{3}{*}{ Dependent variable } & \multicolumn{6}{|c|}{ Log real wage per month (2010 Nepal rupees) } \\
\hline & \multicolumn{2}{|c|}{ All } & \multicolumn{2}{|c|}{ Formal sector } & \multicolumn{2}{|c|}{ Informal sector } \\
\hline & (1) & (2) & (3) & (4) & $(5)$ & (6) \\
\hline Years of schooling & $\begin{array}{c}0.044 * * * \\
(0.006)\end{array}$ & & $\begin{array}{c}0.051 * * * \\
(0.005)\end{array}$ & & $\begin{array}{c}0.057 * * * \\
(0.008)\end{array}$ & \\
\hline \multicolumn{7}{|c|}{ Schooling by category (relative to less than primary, 0-4 years of school): } \\
\hline $\begin{array}{l}\text { Completed primary to } \\
\text { less than secondary ( } 5-9 \text { years of school) }\end{array}$ & & $\begin{array}{c}0.103 * * \\
(0.050)\end{array}$ & & $\begin{array}{c}0.166 * * * \\
(0.046)\end{array}$ & & $\begin{array}{c}0.280 * * * \\
(0.058)\end{array}$ \\
\hline $\begin{array}{l}\text { Completed secondary to less than } \\
\text { higher secondary (10-11 years of school) }\end{array}$ & & $\begin{array}{c}0.340 * * * \\
(0.065)\end{array}$ & & $\begin{array}{c}0.354 * * * \\
(0.067)\end{array}$ & & $\begin{array}{c}0.602 * * * \\
(0.079)\end{array}$ \\
\hline $\begin{array}{l}\text { Completed higher secondary or more } \\
\text { (12 or more years of school) }\end{array}$ & & $\begin{array}{l}0.730 * * * \\
(0.112)\end{array}$ & & $\begin{array}{c}0.663 * * * \\
(0.058)\end{array}$ & & $\begin{array}{l}0.653 * * * \\
(0.154)\end{array}$ \\
\hline Individual controls & $\mathrm{Y}$ & $\mathrm{Y}$ & Y & $\mathrm{Y}$ & Y & $\mathrm{Y}$ \\
\hline Observations & 5,234 & 5,234 & 2,121 & 2,121 & 3,113 & 3,113 \\
\hline R-squared (within) & 0.401 & 0.405 & 0.275 & 0.276 & 0.365 & 0.365 \\
\hline Number of districts & 69 & 69 & 69 & 69 & 69 & 69 \\
\hline
\end{tabular}

Source: Authors' calculations.

Note: Time and district fixed effects included. Standard errors clustered at the district level, in parentheses.

$*$ significant at $10 \%, * *$ at $5 \%, * * *$ at $1 \%$. 
Table A.4b Testing exclusion restrictions, including spatially lagged weather shock and climate variables in own district (employment outcomes only)

\begin{tabular}{|c|c|c|c|c|c|c|c|c|c|c|}
\hline \multirow{4}{*}{ Varible } & \multicolumn{10}{|c|}{ Employed (worked in last 12 months) } \\
\hline & $\operatorname{IV}(1)$ & $\operatorname{IV}(2)$ & $\operatorname{IV}(1)$ & $\operatorname{IV}(2)$ & $\operatorname{IV}(1)$ & $\mathrm{IV}(2)$ & $\operatorname{IV}(1)$ & $\operatorname{IV}(2)$ & $\operatorname{IV}(1)$ & $\operatorname{IV}(2)$ \\
\hline & \multicolumn{2}{|c|}{ All } & \multicolumn{2}{|c|}{$\begin{array}{l}\text { Formal sector } \\
\text { (unconditional) }\end{array}$} & \multicolumn{2}{|c|}{$\begin{array}{c}\text { Informal sector } \\
\text { (unconditional) }\end{array}$} & \multicolumn{2}{|c|}{ High skill } & \multicolumn{2}{|c|}{ Low skill } \\
\hline & (1) & (2) & (3) & (4) & (5) & (6) & (7) & (8) & (9) & (10) \\
\hline $\begin{array}{l}\text { Net Migration Rate } \\
\text { (cumulative } 4 \text { year) }\end{array}$ & $\begin{array}{c}-1.071 * * * \\
(0.323)\end{array}$ & $\begin{array}{c}-1.122^{* * * *} \\
(0.329)\end{array}$ & $\begin{array}{l}1.240^{*} \\
(0.739)\end{array}$ & $\begin{array}{l}1.497^{*} \\
(0.829)\end{array}$ & $\begin{array}{c}-2.292 * * * \\
(0.873)\end{array}$ & $\begin{array}{c}-2.600 * * * \\
(0.984)\end{array}$ & $\begin{array}{l}-1.668^{*} \\
(0.916)\end{array}$ & $\begin{array}{c}-1.551^{*} \\
(0.890)\end{array}$ & $\begin{array}{c}-0.956^{* *} \\
(0.377)\end{array}$ & $\begin{array}{c}-1.008 * * * \\
(0.380)\end{array}$ \\
\hline Spatially Lagged Flood in & -0.218 & -0.191 & -1.117 & -1.255 & 0.918 & 1.084 & 0.676 & 0.632 & -0.390 & -0.363 \\
\hline heavy monsoon at $\mathrm{t}-1$ & $(0.498)$ & $(0.508)$ & $(1.231)$ & $(1.270)$ & $(1.382)$ & $(1.441)$ & $(1.171)$ & $(1.171)$ & $(0.580)$ & $(0.589)$ \\
\hline Spatially Lagged Drought in & $-0.113^{* * *}$ & $-0.114 * * *$ & -0.050 & -0.045 & -0.064 & -0.070 & 0.016 & 0.022 & $-0.118 * * *$ & $-0.119 * * *$ \\
\hline regular monsoon at t-1 & $(0.034)$ & $(0.034)$ & $(0.082)$ & $(0.082)$ & $(0.091)$ & $(0.091)$ & $(0.104)$ & $(0.106)$ & $(0.035)$ & $(0.036)$ \\
\hline RD*Spatially Lagged Flood in & 1.384 & 1.231 & 6.685 & 7.461 & -5.423 & -6.355 & -2.999 & -2.776 & 2.294 & 2.139 \\
\hline heavy monsoon at $\mathrm{t}-1$ & $(2.813)$ & $(2.866)$ & $(7.024)$ & $(7.203)$ & (7.753) & $(8.036)$ & $(6.513)$ & $(6.503)$ & (3.335) & $(3.378)$ \\
\hline RD*Spatially Lagged Drought in & 0.296 & 0.314 & -0.165 & -0.252 & 0.461 & 0.566 & -0.832 & -0.877 & 0.476 & 0.493 \\
\hline regular monsoon at $\mathrm{t}-1$ & $(0.454)$ & $(0.459)$ & $(0.849)$ & $(0.842)$ & $(1.082)$ & $(1.091)$ & $(1.031)$ & $(1.029)$ & $(0.513)$ & $(0.517)$ \\
\hline Spatially Lagged Total conflicts & -2.482 & -3.367 & 19.296 & 23.784 & -21.672 & -27.054 & -23.142 & -20.972 & -0.118 & -0.953 \\
\hline per square $\mathrm{KM}$ at $\mathrm{t}-1$ & $(6.646)$ & $(6.866)$ & $(14.815)$ & $(16.150)$ & $(17.738)$ & $(19.591)$ & $(18.577)$ & $(18.027)$ & (7.884) & $(8.104)$ \\
\hline HH Head Controls & $\mathrm{Y}$ & $\mathrm{Y}$ & $\mathrm{Y}$ & $\mathrm{Y}$ & $\mathrm{Y}$ & $\mathrm{Y}$ & $\mathrm{Y}$ & $\mathrm{Y}$ & $\mathrm{Y}$ & $\mathrm{Y}$ \\
\hline Observations & 7,965 & 7,965 & 7,967 & 7,967 & 7,966 & 7,966 & 1,358 & 1,358 & 6,604 & 6,604 \\
\hline R-squared & 0.082 & 0.082 & 0.055 & 0.055 & 0.040 & 0.040 & 0.088 & 0.088 & 0.090 & 0.090 \\
\hline Number of districts & 69 & 69 & 69 & 69 & 69 & 69 & 64 & 64 & 69 & 69 \\
\hline
\end{tabular}

Source: Authors' calculations.

Note: $\quad$ IV = Independent variable; $\mathrm{km}=$ kilometers; $\mathrm{HH}=$ Household. $\mathrm{RD}=$ River density. Time and district fixed effects included. High skill refers to those individuals with at least 10 years of education. Standard errors, clustered at the district level, in parentheses. * significant at $10 \%$; ** at $5 \%$; *** at $1 \%$. 
Table A.4c Testing exclusion restrictions, including spatially lagged weather shock and climate variables in own district (wage outcomes only)

\begin{tabular}{l|cc|cccc}
\hline \hline \multirow{2}{*}{ Varible } & \multicolumn{5}{|c}{ Log Monthly Real Wage (2010 Nepal Rupees) } \\
& IV(1) & IV(2) & IV(1) & IV(2) & IV(1) & IV(2) \\
\hline & \multicolumn{3}{|c|}{ All } & \multicolumn{2}{c}{ High skill } & \multicolumn{3}{c}{ Low skill } \\
& $(1)$ & $(2)$ & $(3)$ & $(4)$ & $(5)$ & $(6)$ \\
\hline \hline Net Migration Rate & $1.319^{* * *}$ & $1.383^{* * *}$ & $1.950^{* *}$ & $1.860^{* *}$ & $1.305^{* * *}$ & $1.381^{* * *}$ \\
(cumulative 4year) & $(0.363)$ & $(0.378)$ & $(0.850)$ & $(0.872)$ & $(0.395)$ & $(0.406)$ \\
Spatially Lagged Flood in & -0.093 & -0.127 & -0.170 & -0.136 & -0.039 & -0.079 \\
heavy monsoon at t-1 & $(0.580)$ & $(0.599)$ & $(1.205)$ & $(1.217)$ & $(0.614)$ & $(0.633)$ \\
Spatially Lagged Drought in & 0.087 & 0.088 & 0.005 & 0.000 & 0.089 & 0.090 \\
regular monsoon at t-1 & $(0.058)$ & $(0.058)$ & $(0.108)$ & $(0.108)$ & $(0.057)$ & $(0.057)$ \\
RD*Spatially Lagged Flood in & 0.464 & 0.658 & 0.249 & 0.079 & 0.270 & 0.499 \\
heavy monsoon at t-1 & $(3.414)$ & $(3.515)$ & $(6.787)$ & $(6.838)$ & $(3.607)$ & $(3.705)$ \\
RD*Spatially Lagged Drought in & 0.145 & 0.123 & 1.696 & 1.731 & -0.096 & -0.122 \\
regular monsoon at t-1 & $(0.744)$ & $(0.743)$ & $(1.116)$ & $(1.102)$ & $(0.798)$ & $(0.797)$ \\
Spatially Lagged Total conflicts & -2.953 & -1.831 & 17.950 & 16.292 & -8.021 & -6.789 \\
per square KM at t-1 & $(7.130)$ & $(7.493)$ & $(16.572)$ & $(16.777)$ & $(7.984)$ & $(8.333)$ \\
HH Head Controls & $\mathrm{Y}$ & $\mathrm{Y}$ & $\mathrm{Y}$ & $\mathrm{Y}$ & $\mathrm{Y}$ & $\mathrm{Y}$ \\
Observations & 7,965 & 7,965 & 1,358 & 1,358 & 6,604 & 6,604 \\
R-squared & 0.077 & 0.077 & 0.103 & 0.103 & 0.079 & 0.078 \\
Number of districts & 69 & 69 & 64 & 64 & 69 & 69 \\
\hline \hline
\end{tabular}

Source: Authors' calculations.

Note: $\quad$ IV $=$ Independent variable; $\mathrm{HH}=$ Household. $\mathrm{RD}=$ River density. Time and district fixed effects included. High skill refers to those individuals with at least 10 years of education. Standard errors, clustered at the district level, in parentheses. ${ }^{\star}$ significant at $10 \%$; ${ }^{\star \star}$ at $5 \%$; ${ }^{\star \star \star}$ at $1 \%$.

Table A.5 Reduced form regressions of predicted migration on wages

\begin{tabular}{|c|c|c|c|c|c|c|c|c|c|c|}
\hline \multirow[t]{3}{*}{ Varible } & \multicolumn{10}{|c|}{ Log monthly real wage (2010 Nepal Rupees) } \\
\hline & \multicolumn{3}{|c|}{ All } & \multirow{2}{*}{$\begin{array}{l}\text { Formal sector } \\
\text { (4) }\end{array}$} & \multicolumn{2}{|c|}{ Informal sector } & \multicolumn{2}{|c|}{ High skill } & \multicolumn{2}{|c|}{ Low skill } \\
\hline & (1) & (2) & (3) & & $(5)$ & (6) & (7) & (8) & (9) & $(10)$ \\
\hline $\begin{array}{l}\text { Predicted Net Migration Rate } \\
\text { (cumulative 4year) }\end{array}$ & $\begin{array}{l}3.0680 \\
(5.162)\end{array}$ & & $\begin{array}{c}-9.2770 * * * \\
(3.051)\end{array}$ & & $\begin{array}{r}10.5879 \\
(5.563)\end{array}$ & & $\begin{array}{l}-2.7469 \\
(3.408)\end{array}$ & & $\begin{array}{l}7.1979 \\
(5.370)\end{array}$ & \\
\hline $\begin{array}{l}\text { Predicted Out Migration Rate } \\
\text { (cumulative 4year) }\end{array}$ & & $\begin{array}{l}-9.4256 \\
(5.774)\end{array}$ & & $\begin{array}{l}-1.4470 \\
(4.068)\end{array}$ & & $\begin{array}{l}-11.7298 \\
(7.745)\end{array}$ & & $\begin{array}{c}2.4459 \\
(11.232)\end{array}$ & & $\begin{array}{c}-12.5513^{* *} \\
(5.933)\end{array}$ \\
\hline $\begin{array}{l}\text { Predicted In Migration Rate } \\
\text { (cumulative 4year) }\end{array}$ & & $\begin{array}{l}0.1133 \\
(5.930)\end{array}$ & & $\begin{array}{c}-13.4314 * * * \\
(2.785)\end{array}$ & & $\begin{array}{l}9.9432 \\
(7.382)\end{array}$ & & $\begin{array}{r}-2.8377 \\
(4.601)\end{array}$ & & $\begin{array}{l}4.1768 \\
(6.544)\end{array}$ \\
\hline HH Head Controls & Y & Y & $\mathrm{Y}$ & Y & $\mathrm{Y}$ & $\mathrm{Y}$ & Y & $\mathrm{Y}$ & $\mathrm{Y}$ & $\mathrm{Y}$ \\
\hline Observations & 5,234 & 5,234 & 2,121 & 2,121 & 3,113 & 3,113 & 1,080 & 1,080 & 4,154 & 4,154 \\
\hline R-squared & 0.510 & 0.510 & 0.282 & 0.283 & 0.367 & 0.367 & 0.463 & 0.463 & 0.481 & 0.482 \\
\hline Number of districts & 69 & 69 & 69 & 69 & 69 & 69 & 65 & 65 & 69 & 69 \\
\hline
\end{tabular}

Source: Authors' calculations.

Note: $\quad$ IV $=$ Independent variable; $\mathrm{HH}=$ Household. High skill refers to those individuals with at least 10 years of education. Time and district fixed effects included. Standard errors, clustered at the district level, in parentheses. * significant at $10 \%$; ** at $5 \%$; *** at $1 \%$. 
Table A.6 Reduced form regressions of predicted migration on employment

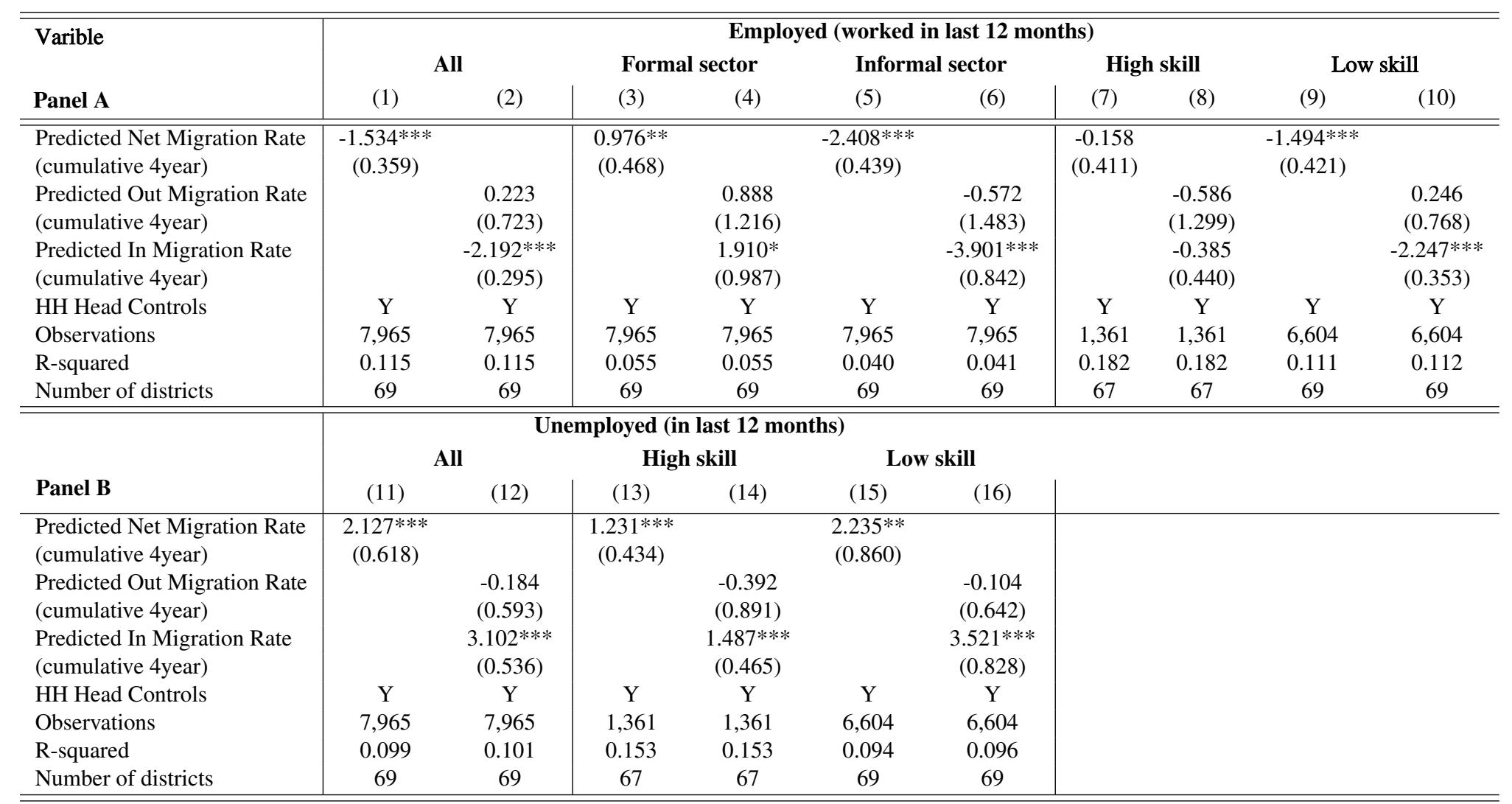

Source: Authors' calculations.

Note: IV = Independent variable; $\mathrm{HH}=$ Household. High skill refers to those individuals with at least 10 years of education. Time and district fixed effects included. Standard errors, clustered at the district level, in parentheses. * significant at $10 \% ; * *$ at $5 \%$; ${ }^{* * *}$ at $1 \%$. 


\section{REFERENCES}

Adams, R., and J. Page. 2005. "Do International Migration and Remittances Reduce Poverty in Developing Countries?" World Development 33(10): 1645-1669.

Alix-Garcia, J., and A. Bartlett. 2012. "Occupations under Fire: The Labor Market in a Complex Emergency," Unpublished, Department of Agricultural and Applied Economics, University of Wisconsin, Madison, WI, US.

Alix-Garcia, J., A. Bartlett, and D. Saah. 2013. "The Landscape of Conflict: IDPs, Aid, and Land Use Change in Darfur." Journal of Economic Geography 13(4): 589-617.

Altonji, J. G., and D. Card. 1991. "The Effects of Immigration on the Labor Market outcomes of Less-skilled Natives.," In Immigration, Trade and Labor, edited by J. Abowd and R. Freeman, 201-234. Chicago: University of Chicago Press.

Anselin, L. 2002. "Under the Hood: Issues in the Specification and Interpretation of Spatial Regression Models." Agricultural Economics 27(3): 247-267.

Arellano, M., and S. Bond. 1991. "Some Tests of Specification for Panel Data. Monte Carlo Evidence and an Application to Employment Equations." Review of Economic Studies, 58: 277-297.

Banister, J., and S. Thapa. 1981. "The Population Dynamics of Nepal.” Honolulu: East-West Population Institute.

Beegle, K., J. De Weerdt, and S. Dercon. 2011. "Migration and Economic Mobility in Tanzania: Evidence from a Tracking Survey." Review of Economics and Statistics 93(3): 1010-1033.

Blundell, R. W., and S. Bond. 1998. "Initial Conditions and Moment Restrictions in Dynamic Panel Data Models." Journal of Econometrics 87(1): 115-143.

Bohra-Mishra, P. 2011. "Migration and Remittances during the Period of Civil Conflict in Nepal," Ph.D. thesis, Woodrow Wilson School of Public and International Affairs, Princeton University, NJ, US.

Bohra-Mishra, P., M. Oppenheimer, and S. Hsiang. 2014. "Nonlinear Permanent Migration Response to Climate Variations," Unpublished, Woodrow Wilson School of Public and International Affairs, Program in Science Technology and Environmental Policy, Princeton University, NJ, US.

Borjas, G. 2003. "The Labor Demand Curve is Downward Sloping: Reexamining the Impact of Immigration on the Labor Market.," Quarterly Journal of Economics 118(4): 1335-1374.

2005. "The Labor Market Impact of High-Skill Immigration.” The American Economic Review 95(2): 56-60.

- 2006. "Native Internal Migration and the Labor Market Impact of Immigration," Journal of Human Resources, 41(2): 221-258.

Borjas, G., and L. Katz. 2007. "The Evolution of the Mexican-Born Work- force in the United States.," in Mexican Immigration to the United States, edited by G. Borjas, 13-55. Cambridge, MA, US: National Bureau of Economic Research.

Boustan, L., P. Fishback, and S. Kantor. 2010. "The Effect of Internal Migration on Local Labor Markets: American cities during the Great Depression." Journal of Labor Economics 28(4): 719-746.

Card, D. 1990. "The Impact of the Mariel Boatlift on the Miami Labour Markets." Industrial and Labor Relations Review 43(2): 245-257.

_. 2005. "Is the New Immigration Really So Bad?” Economic Journal 115(507): 300-323.

Card, D., and T. Lemieux. 2001. "Can Falling Supply Explain the Rising Return to College for Younger Men? A Cohort-Based Analysis." Quarterly Journal of Economics 116: 705-746. 
Conley, T. G. 1999. “GMM Estimation with Cross Sectional Dependence.” Journal of Econometrics 92: $1-45$.

Cortes, P. 2008. "The Effect of Low-Skilled Immigration on US Prices: Evidence from CPI Data." Journal of Political Economy 116(3): 381-422.

CRED (Centre for Research on the Epidemiology of Disasters). 2014. EM-DAT: The OFDA/CRED International Disaster Database. Accessed January 30. www.emdat.be/.

Dartmouth Flood Observatory. 2014. Global Active Archive of Large Flood Events. Accessed January 30. http://floodobservatory.colorado.edu/.

De Brauw, A., V. Mueller, and T. Woldehanna. 2013. "Motives to Remit: Evidence from Tracked Internal Migrants in Ethiopia." World Development 50: 13-23.

de Mel, S., D. J. McKenzie, and C. Woodruff. 2012. "Enterprise Recovery Following Natural Disasters" The Economic Journal 122(559): 64-91.

Dillion, A., V. Mueller, and S. Salau. 2011. "Migratory Responses to Agricultural Risk in Northern Nigeria." American Journal of Agricultural Economics 93(4): 1048-1061.

Do, Q.-T., and L. Iyer. 2010. “Geography, Poverty and Conflict in Nepal.” Journal of Peace Research 47(6): $735-748$.

El Badaoui, E., E. Strobl, and F. Walsh. 2014. "The Impact of Internal Migration on Local Labour Markets in Thailand.” Working Papers 2014- 071, Paris: Department of Research, Ipag Business School.

Fafchamps, M., and S. Shilpi. 2013. "Determinants of the Choice of Migration Destination." Oxford Bulletin of Economics and Statistics 75(3): 0305-9049.

Feng, S., A. Krueger, and M. Oppenheimer. 2010. "Linkages among Climate Change, Crop Yields and Mexico-US Cross-Border Migration." Proceedings of the National Academy of Sciences of the United States of America 107(32): 14257-14262.

Gray, C., and R. Bilsborrow. 2013. "Environmental Influences on Human Migration in Rural Ecuador." Demography 50(4): 1217-1241.

Gray, C., and V. Mueller. 2012a. "Drought and Population Mobility in Rural Ethiopia." World Development, 40(1): 134-145.

_ 2012b. "Natural Disasters and Population Mobility in Bangladesh." Proceedings of the National Academy of Sciences of the United States of America 109(16): 6000-6005.

Green, W. H. 2003. Econometric Analysis. New Jersey: Prentice-Hall.

Grogger, J., and G. Hanson. 2011. "Income Maximization and the Selection and Sorting of International Migrants." Journal of Development Economics 95(1): 42-57.

Halliday, T. 2006. "Migration, Risk, and Liquidity Constraints in El Salvador." Economic Development and Cultural Change 54(4): 893-926.

Hanson, G. 2009. "The Economic Consequences of the International Migration of Labor." Annual Review of Economics 1: 179-208.

Hsiang, S. 2010. "Temperatures and Cyclones Strongly Associated with Economic Production in the Caribbean and Central America." Proceedings of the National Academy of Sciences of the United States of America 107(35): 15367-15372.

ILO (International Labor Organization) and Government of Nepal, National Planning Commission. 2010. Labor and Social Trends in Nepal 2010. ILO Report. Geneva: ILO.

IPCC (Intergovernmental Panel on Climate Change). 2014. Climate Change 2014 - Impacts, Adaptation and Vulnerability. Geneva. Unpublished. 
Johnson, G. E. 1980a. “The Labor Market Effects of Immigration.” Industrial and Labor Relations Review 33(3): 331-341.

1980b. "The Theory of Labour Market Intervention.” Economica 47(187): 309-329.

Kerr, W. R. 2013. “U.S. High-Skilled Immigration, Innovation, and Entrepreneurship: Empirical Approaches and Evidence,” Working Paper 14-017. Cambridge, MA, US: Harvard Business School.

Kleemans, M., and J. Magruder. 2012. "Labor Markets Changes in Response to Immigration: Evidence from Internal Migration Driven by Weather Shocks in Indonesia." Department of Agricultural and Resource Economics, University of California, Berkley, US.

Kondylis, F. 2010. “Conflict Displacement and Labor Market Outcomes in Post-War Bosnia and Herzegovina.” Journal of Development Economics 93, 235-248.

Lach, S. 2007. "Immigration and Prices.” Journal of Political Economy 115(4): 548-587.

Maddala, G. S., and S. Wu. 1999. “A Comparative Study of Unit Root Tests with Panel Data and a New Simple Test.” Oxford Bulletin of Economics and Statistics 61, 631-652.

Marchiori, L., J.-F. Maystadt, and I. Schumacher. 2012. "The Impact of Climate Variations and Migration in Sub-Saharan Africa," Journal of Environmental Economics and Management, 63(3): 355-374.

Massey, D., W. Axinn, and G. D.J. 2010. "Environmental Change and Out-Migration: Evidence from Nepal.” Population and Environment 32(2): 109-136.

Maystadt, J.-F., and P. Verwimp. 2014. "Winners and Losers among a Refugee-Hosting Population." Economic Development and Cultural Change, forthcoming.

Mueller, V., C. Gray, and K. Kosec. 2014. "Heat Stress Increases Long- term Human Migration in Rural Pakistan." Nature Climate Change 4: 182- 185.

Munshi, K. 2003. "Networks in the Modern Economy: Mexican Migrants in the U.S. Labor Market." Quarterly Journal of Economics 118(2): 549-599.

Murshed, S., and S. Gates. 2005. "Spatial-Horizontal Inequality and the Maoist Insurgency in Nepal." Review of Development Economics 9(1): 121-134.

NASA (US National Aeronautics and Space Administration). 2014. POWER (Prediction of Worldwide Energy Resource) database. NASA Earth Science Directorate Applied Science Program. Accessed January 30, 2014. http://power.larc.nasa.gov.

Ottaviano, G., and G. Peri 2012. "Rethinking the Effects of Immigration on Wages." Journal of the European Economic Association 10(1): 152-197.

Pugatch, T., and D. Yang 2011. "The Impact of Mexican Immigration on U.S. Labor Markets: Evidence from Migrant Flows Driven by Rainfall Shocks.” University of Michigan, Ann Arbor, US.

Raleigh, C., A. Linke, H. Hegre, and J. Karlsen 2010. "Introducing ACLED: An Armed Conflict Location and Event Dataset." Journal of Peace Research 47(5): 1-10.

Saiz, A. 2003. "Room in the Kitchen for the Melting Pot: Immigration and Rental Prices," Review of Economics and Statistics 85(3): 502-521.

2007. "Immigration and Housing Rents in American Cities." Journal of Urban Economics 61: 345-371.

Shrestha, S. S. and P. Bhandari. 2007. "Environmental Security and Labor Migration in Nepal," Population and Environment 29: 25-38.

Shrestha, V. P. 1999. "Forest Resources of Nepal: Destruction and Environmental Implications" Contributions to Nepalese Studies 26(3): 295-307. 
Stock, J., and J. H. Yogo. 2005): “Testing for weak instruments in IV Regression" In Identification and Inference for Econometrics Models: A Festschrift in Honor of Thomas Rothenberg, edited by J. H. Stock, 80-108. Cambridge: Cambridge University Press.

Strobl, E., and M.-A. Valfort. 2013. "The Effect of Weather-Induced Internal Migration on Local Labor Markets: Evidence from Uganda." World Bank Economic Review. Published electronically October 21, 2013. doi:10.1093/wber/lht029.

UNOCHA (Office for the Coordination of Humanitarian Affairs). 2008. Nepal Humanitarian Transition Appeal. Accessed January 30, 2014. https //docs.unocha.org/sites/dms/CAP/2009N epalH TAV OL1S CREEN.pdf.

- 2009. Nepal FWR/MWR Floods and Landslides. Situation Report 2.UNOCHA. Accessed January 30, 2014. www.un.org.np/sites/default/files/situation_updates/tid_188/2009-10-13-Ocha-SitrepNo2MFWRFloods.pdf.

Wang, S.-Y., J.-H. Yoon, and R. Gillies. 2013. "What Caused the Winter Drought in Western Nepal during Recent Years?” Journal of Climate 26(21): 8241-8256.

Woodruff, C., and R. Zenteno. 2007. "Migration Networks and Microenterprises in Mexico." Journal of Development Economics 82(2): 509-528.

Yang, D. 2008. "International Migration, Remittances, and Household Investment: Evidence from Philippine Migrants' Exchange Rate Shocks," Economic Journal 118(528): 591-630. 



\section{RECENT IFPRI DISCUSSION PAPERS}

\section{For earlier discussion papers, please go to www.ifpri.org/pubs/pubs.htm\#dp. All discussion papers can be downloaded free of charge.}

1363. The role of agriculture in the fast-growing Rwandan economy: Assessing growth alternatives. Xinshen Diao, Godfrey Bahiigwa, and Angga Pradesha, 2014.

1362. Understanding the context for agriculture for nutrition research: Identifying country typologies of child-stunting determinants. Eduardo Maruyama, Laurian J. Unnevehr, and Jiarui Wang, 2014.

1361. Assessing the economic benefits of sustainable land management practices in Bhutan. Ephraim Nkonya, Raghavan Srinivasan, Weston Anderson, and Edward Kato, 2014.

1360. Examining the sense and science behind Ghana's current blanket fertilizer recommendation. Antony Chapoto and Francis Tetteh, 2014.

1359. Aid effectiveness in Ghana: How's the L'Aquila Food Security Initiative doing? Samuel Benin, Tsitsi Makombe, and Michael Johnson, 2014.

1358. The other Asian enigma: Explaining the rapid reduction of undernutrition in Bangladesh. Derek D. Headey, John Hoddinott, Disha Ali, Roman Tesfaye, and Mekdim Dereje, 2014.

1357. Can market-based approaches to technology development and dissemination benefit women smallholder farmers?: A qualitative assessment of gender dynamics in the ownership, purchase, and use of irrigation pumps in Kenya and Tanzania. Jemimah Njuki, Elizabeth Waithanji, Beatrice Sakwa, Juliet Kariuki, Elizabeth Mukewa, John Ngige, 2014.

1356. The impact of shocks on gender-differentiated asset dynamics in Bangladesh. Muntaha Rakib and Julia Anna Matz, 2014.

1355. Tractor owner-operators in Nigeria: Insights from a small survey in Kaduna and Nasarawa States. Hiroyuki Takeshima, Hyacinth Edeh, Akeem Lawal, and Moshud Isiaka, 2014.

1354. Co-movement of major commodity price returns: A time-series assessment. Francesca de Nicola, Pierangelo De Pace, and Manuel A. Hernandez, 2014.

1353. Bargaining power and biofortification: The role of gender in adoption of orange sweet potato in Uganda. Daniel O. Gilligan, Neha Kumar, Scott McNiven, J. V. Meenakshi, and Agnes Quisumbing, 2014.

1352. Quality healthcare and health insurance retention: Evidence from a randomized experiment in the Kolkata Slums. Clara Delavallade, 2014.

1351. Sins of the fathers: The intergenerational legacy of the 1959-1961 Great Chinese Famine on children's cognitive development. Chih Ming Tan, Zhibo Tan, and Xiaobo Zhang, 2014.

1350. Direct seed marketing program in Ethiopia in 2013: An operational evaluation to guide seed-sector reform. Todd Benson, David Spielman, and Leulsegged Kasa, 2014.

1349. Agriculture for development in Iraq?: Estimating the impacts of achieving the agricultural targets of the National Development Plan 2013-2017 on economic growth, incomes, and gender equality. Azhr Al-Haboby, Clemens Breisinger, Dario Debowicz, Abdul Hussein El-Hakim, Jenna Ferguson, Roberto Telleria, and Teunis van Rheenen, 2014.

1348. An evaluation of the effectiveness of farmland protection policy in China. Man Li, 2014.

1347. Women's individual and joint property ownership: Effects on household decisionmaking. Cheryl Doss, Sung Mi Kim, Jemimah Njuki, Emily Hillenbrand, and Maureen Miruka, 2014.

1346. Can smallholder fruit and vegetable production systems improve household food security and nutritional status of women?: Evidence from rural Uganda. Nassul Kabunga, Shibani Ghosh, and Jeffrey K. Griffiths, 2014.

1345. Intellectual property rights, technology diffusion, and agricultural development: Cross-country evidence. David J. Spielman and Xingliang Ma, 2014.

1344. Market interdependence and volatility transmission among major crops. Cornelis Gardebroek Manuel A. Hernandez, and Miguel Robles, 2014.

1343. Importance of rice research and development in rice seed policies: Insights from Nigeria. Hiroyuki Takeshima, 2014.

1342. Can transfer programs be made more nutrition sensitive? Harold Alderman, 2014. 


\section{INTERNATIONAL FOOD POLICY RESEARCH INSTITUTE}

www.ifpri.org

IFPRI HEADQUARTERS

2033 K Street, NW

Washington, DC 20006-1002 USA

Tel.: +1-202-862-5600

Fax: +1-202-467-4439

Email: ifpri@cgiar.org 